\title{
Diagenesis, provenance and reservoir quality of Triassic TAGI sandstones from Ourhoud field, Berkine (Ghadames) Basin, Algeria
}

\author{
C. Rossi ${ }^{\mathrm{a}, *}$, O. Kälin ${ }^{\mathrm{b}}$, J. Arribas ${ }^{\mathrm{a}}$, A. Tortosa ${ }^{\mathrm{a}}$

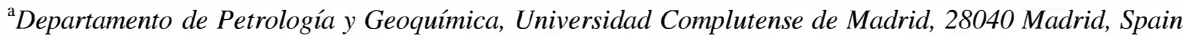 \\ ${ }^{\mathrm{b}}$ Departamento de Paleontología, Universidad Complutense, 28040 Madrid, Spain
}

\begin{abstract}
The Triassic TAGI (Trias Argilo-Gréseux Inférieur) fluvial sandstones are the main oil reservoirs in the Berkine Basin, Algeria. Nonetheless, their provenance and diagenesis, and their impact on reservoir quality, are virtually unknown. Samples from the Ourhoud field, representing the Lower, Middle and Upper TAGI subunits, were studied using a combination of petrographic, mineralogical and geochemical techniques. The Lower TAGI sandstones have an average framework composition of $\mathrm{Q}_{98.3} \mathrm{~F}_{0.6} \mathrm{R}_{1.1}$ and $95 \%$ of the quartz grains are monocrystalline. By contrast, the Middle-Upper TAGI sandstones have an average framework composition of $\mathrm{Q}_{88.3} \mathrm{~F}_{9.8} \mathrm{R}_{1.9}$ and $79.7 \%$ of the quartz grains are monocrystalline. The Lower TAGI quartz arenites derived from Paleozoic siliciclastic rocks, whereas the Middle-Upper TAGI subarkoses originated mainly from metamorphic terrains. This change in provenance is a potential criterion for correlation within the TAGI. Also, this change has contributed to the significantly different diagenetic paths followed by the Lower TAGI quartz arenites and the MiddleUpper TAGI subarkoses.

Grain-coating illitic clays are abundant in the Lower TAGI, where they exert a critical control on reservoir quality. These clays are interpreted as pedogenic and/or infiltrated in origin and to have had, in part, smectitic precursors. Shallow burial Fe-dolomite cementation was favored in the downthrown block of the field-bounding fault, where it contributed to the poor reservoir quality. Magnesite-siderite cements are multiphase. The earliest generation is composed of Fe-rich magnesite that precipitated during shallow burial from hypersaline fluids with high $\mathrm{Mg} / \mathrm{Ca}$ ratios, probably refluxed residual brines associated with the Liassic evaporites. Later magnesite-siderite generations precipitated during deeper burial from waters with progressively higher Fe/Mg ratios. Authigenic vermicular kaolin largely consists of dickite that replaced previously formed kaolinite. Dickitization was followed by late-stage illitization related to the dissolution of detrital and authigenic K-feldspar. Quartz, the most abundant cement, was mainly sourced by the pressure- or clay-induced dissolution of detrital quartz and is a critical factor controlling the reservoir quality. Overall, quartz cement is more abundant in the Lower TAGI than in the MiddleUpper TAGI, and this increase correlates with a decrease in average porosity. Within the Lower TAGI, quartz cement abundance is stratigraphically very variable, which is in part related to facies controlled variations in grain-coating clay, resulting in major vertical variations in reservoir quality. Anhydrite and barite cements postdate quartz overgrowth. The sulfate necessary for their formation was likely sourced by deep subsurface dissolution of Late Triassic-Liassic evaporites.
\end{abstract}

Keywords: Sandstone diagenesis; Reservoir quality; Berkine basin; Triassic; Algeria

\section{Introduction}

Detrital composition can critically influence the reservoir quality of sandstones by conditioning the pathway of both physical and chemical diagenesis (e.g. Bloch, 1994). Intraformational variations in detrital composition can thus cause significant heterogeneity in sandstone reservoir quality. Compositional changes respond to variations in climate, depositional facies and, especially, provenance. Recognition of vertical changes in composition resulting from

\footnotetext{
* Corresponding author. Tel.: +34-91-394-5014; fax: +34-91-544-2535. E-mail address: crossi@geo.ucm.es (C. Rossi).
}

changes in provenance thus has great potential for improving stratigraphic resolution on a regional scale and, hence, reservoir correlation. This is especially useful in non-marine sandstones that typically lack age-diagnostic fossils (e.g. Morton \& Hurst, 1995).

The fluvial sandstones of the TAGI (Trias ArgiloGréseux Inférieur) constitute the main oil reservoirs in the Berkine Basin (Algeria). This basin hosts some of the most important recently discovered hydrocarbon accumulations in North Africa (Cochran \& Petersen, 2000; MacGregor, 1998a,b). Although TAGI sandstones have relatively high porosities and permeabilities in many fields, reservoir quality varies greatly across the Basin and within individual 


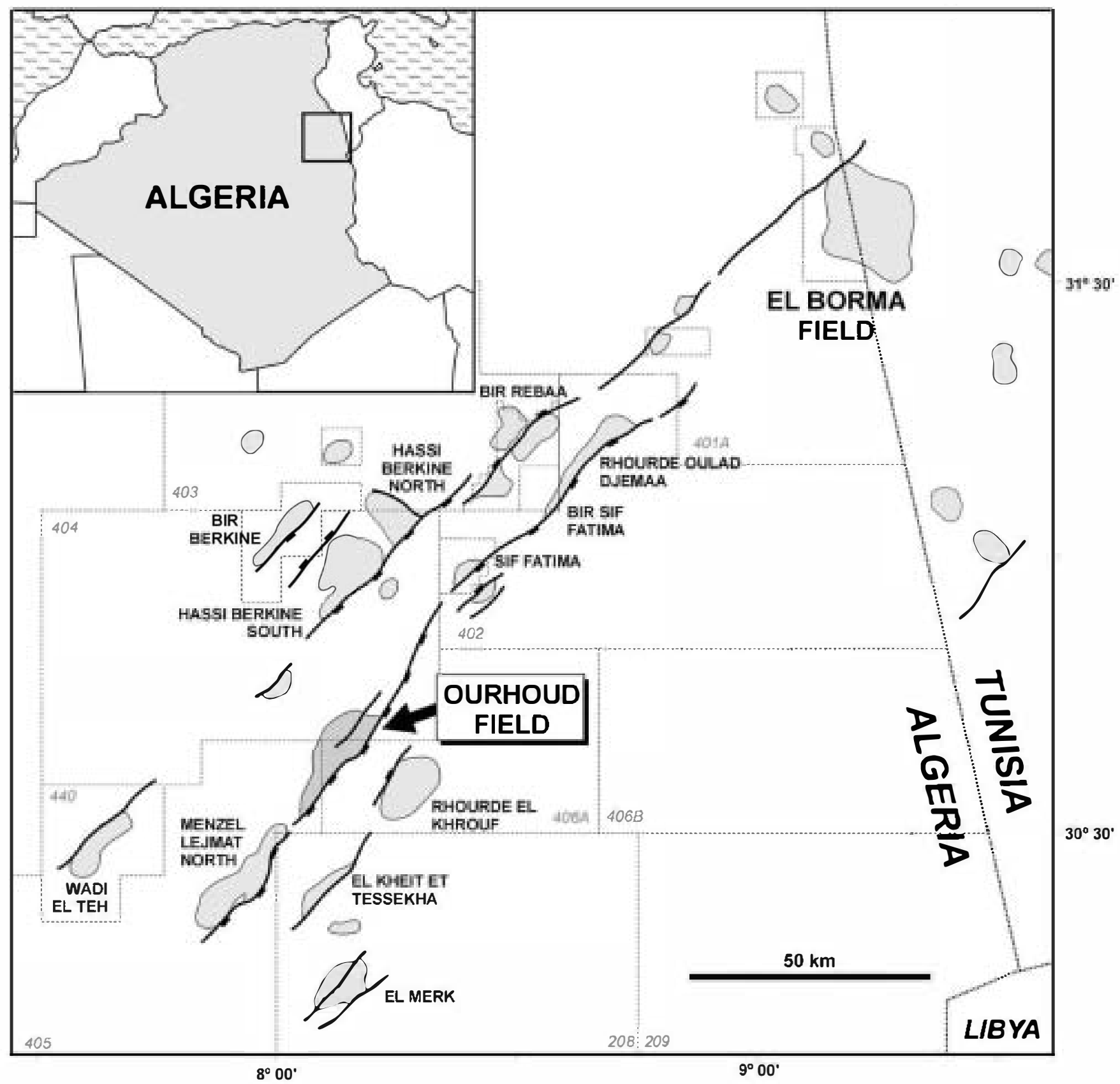

Fig. 1. Location map of the Ourhoud field in the Berkine Basin, Algeria, showing the main oil fields and faults in the area

fields. This has been primarily atributed to the complex depositional architecture (Echikh, 1998). Therefore, considerable research eff ort has been made on the sedimentology and stratigraphy of these deposits (Carney et al., 1999; Scott \& Wheller, 1999; Wheller et al., 1999; Turner et al., 2001). However, little is known $\bullet$ the provenance and diagenesis -f these sandstones, and the implications of these factors for

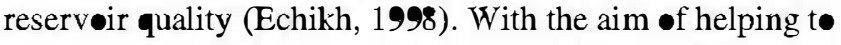
close this gap, this paper describes the compositional and diagenetic features of the TAGI sandstones in tw॰ wells from the Ourhoud field (Fig. 1) and discusses their provenance and diagenetic evolution, as well as the influence of these factors on reservoir quality. In particular, this study reveals that the TAGI succession contains a significant intraformational change in derital composition caused by a change in provenance. This change in composition provides a pøtential criterion for stratigraphic correlation within the TAGI. This paper als illustrates that the reservoir quality of the TAGI sandstones is largely controlled by the distinct pathways of diagenesis followed by the sandstones of the Lower and Middle-Upper parts of the TAGI. This variation in diagenesis is mainly related to differences in initial feldspar content and in syndepositional grain-coating illitic clays. 


\section{Geological background}

The intracratonic Ghadames Basin contains up t॰ $6 \mathrm{~km}$ - P Paleøzic and Mesøzic sediments and stretches •ver parts of eastern Algeria, western Libya and southern Tunisia (Fig. 1) (Acheche, M'Rabet, Ghariani, Ouahchi, \&

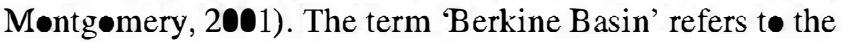
western, Algerian part of the Ghadames Basin (Cøchran \& Petersen, 2000). In the subsurface, the Berkine Basin is limited to the west and north by the Hassi Messaoud and Dahar structural ridges, respectively. Søuthward, the Berkine Basin is separated from the Illizi Basin by the Møle D'Ahara, which acted as a continental paleøhigh during the Mesøzoic and Cenøzøic (Gauthier, Boud jema, \& Lounis, 1995).

The Paleøzic (Cambrian t• Early Carbøniferøus) fill in the Berkine Basin consists of a predominantly siliciclastic succession reaching up to $3.5 \mathrm{~km}$ in thickness (Askri et al., 1995) (Fig. 2). The Hercynian orogeny caused uplift and partial erosion aløng the basin margins. During the early Mesøoic, an extensional basin was superimposed on the pre-existing Paleøzic basin. The Mesøeic basin records sedimentation on a southern continental margin of the Tethyan sea and contains up t॰ $4 \mathrm{~km}$ •f sediments (Bøote, Clark-Lowes, \& Traut, 1998) (Fig. 3). Continental Triassic deposits were deposited over a Hercynian unconformity in a series of northeast-trending grabens that opened to the prot॰-Tethys tøward the nørtheast (Bøud jema, 1987; Jacksøn, Møore, Quarles, \& Bellis, 1996). Prevalent marginal marine conditions since the Late Triassic resulted in a thick succession of Upper Triassic and Liassic evaporites, which are overlain by Late Jurassic t• Early Cretaceous carbonates and siliciclastics (Askri et al., 1995) (Fig. 2).

An early Aptian phase of deformation resulted in strikeslip faulting, løcalized tectonic inversion and uplift (Bøote et al., 1998; Echikh, 1998; Jackson et al., 1996). Renewed late Aptian to Senonian subsidence resulted in the sedimentation of a carbonate- and evaporite-dominated succession,

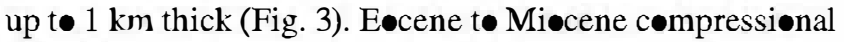
tectonic activity caused subtle folding, uplift, and erosion, especially to the north (Bøote et al., 1998). Tertiary sediments are preserved only in the central parts $\bullet$ the basin and consist of a relatively thin $(<200 \mathrm{~m})$ Miøcene t• Pliøcene succession unconformably •verlying Upper Cretaceous strata.

The Ourhoud (ORD) •il field, subject of the present study, is located within the central part of the Berkine Basin. Here, most of the oil fields discovered lie along a SW-NE oriented rend (Fig. 1). This trend contains at least six fields which have reserves exceeding 250 million barrels of $\bullet$ il equivalent (MMBOE), and three $\bullet$ them (El Borma, Hassi Berkine South, and ORD) have reserves $>1000 \mathrm{MMBOE}$ (Carney et al., 1999; Cøchran \& Petersen, 2000; MacGregør, 1998a,b; Shirley, 2000). Most of this -il is reservoire in TAGI sandstone in structural traps sealed by Liassic evaporites. The traps originated as tilted fault bløcks during the Late Triassic-Liassic extension phase and some of them were later modified by the Aptian transpressive deformation (Bøote et al., 1998; Cochran \& Petersen, 2000; Echikh, 1998; Jacksøn et al., 1996).

Lower Silurian and Upper Devonian (Frasnian) black shales are the primary petroleum source rocks across the whole Saharan Platform, including the Berkine Basin (Makhous, Galushkin, \& Lopatin, 1997; Yahi, Schaefer, \& Littke, 2001). In the northwestern part of the basin, these søurce rocks subcrop the Hercynian unconformity and are thus in direct contact with Triassic sandstones (Fig. 2). This facilitated lateral updip migration to the southeast, charging Triassic sandstones in structural traps sealed by TriassicLiassic mudstones and evaporites. The oil fields of the central part of the Berkine Basin are located a relatively short distance updip of the Devonian subcrop and thus the Frasnian shales constitute the most likely hydrocarbon sources (Fig. 2). In fact, two-dimensional basin modeling and maturity data (Yahi et al., 2001) suppørt the hyp thesis -f a Frasnian source for the ๑ils $\bullet$ According to the same authørs, in the central Berkine Basin petroleum generation from the Frasnian søurce beds peaked during the Late Cretaceus-Tertiary, and these source røcks are currently in a mature to late mature stage.

\subsection{TAGI stratigraphy}

The Carnian TAGI sandstones are present $\bullet$ ver a large part $\bullet$ the Berkine Basin, covering the Hercynian unconformity (Fig. 2). They can exceed $100 \mathrm{~m}$ in thickness and

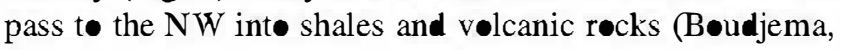
1987). In the central and SW parts of the basin, most TAGI sandstones were deposited in fluvial braidplains that drained NE (Cochran \& Petersen, 2000; Wheller et al., 1999). Stratigraphically upward and toward NE, the braidedriver sandstones grade int $\bullet$ meandering river deposits, which in turn pass in the El Borma area int tide-influenced deltaic sediments (Ben Tahar, 1991; Echikh, 1998). The -verall ransgressive character of the TAGI culminated with the deposition of the cøastal t• shalløw marine shales and carbønates $\bullet$ the 'Triassic Carbønate' unit (Bøudjema, 1987).

The TAGI contains several laterally extensive mudstone intervals (Acheche et al., 2001; Boud jema, 1987), which are interpreted, in part, to be lacustrine in origin (Carney et al., 1999; Wheller et al., 1999). In the central-western part of the Berkine Basin, the presence of these intervals has allowed the subdivision of the TAGI int three main sandstone/mudstone units (i.e. Løwer, Middle and Upper; Fig. 3; Førd and Scott, 1997; Cochran \& Petersen, 2000; Scott \& Howells, 2000). According to Daniels, Hook, Sorensen, and Emme (1994), the lower TAGI is transgressive and represents a third-order sequence. In the ORD field, the Lower TAGI can be further subdivided int three subunits referred to, in the føllowing, as TLl, TL2, and TL3 (Fig. 3). 


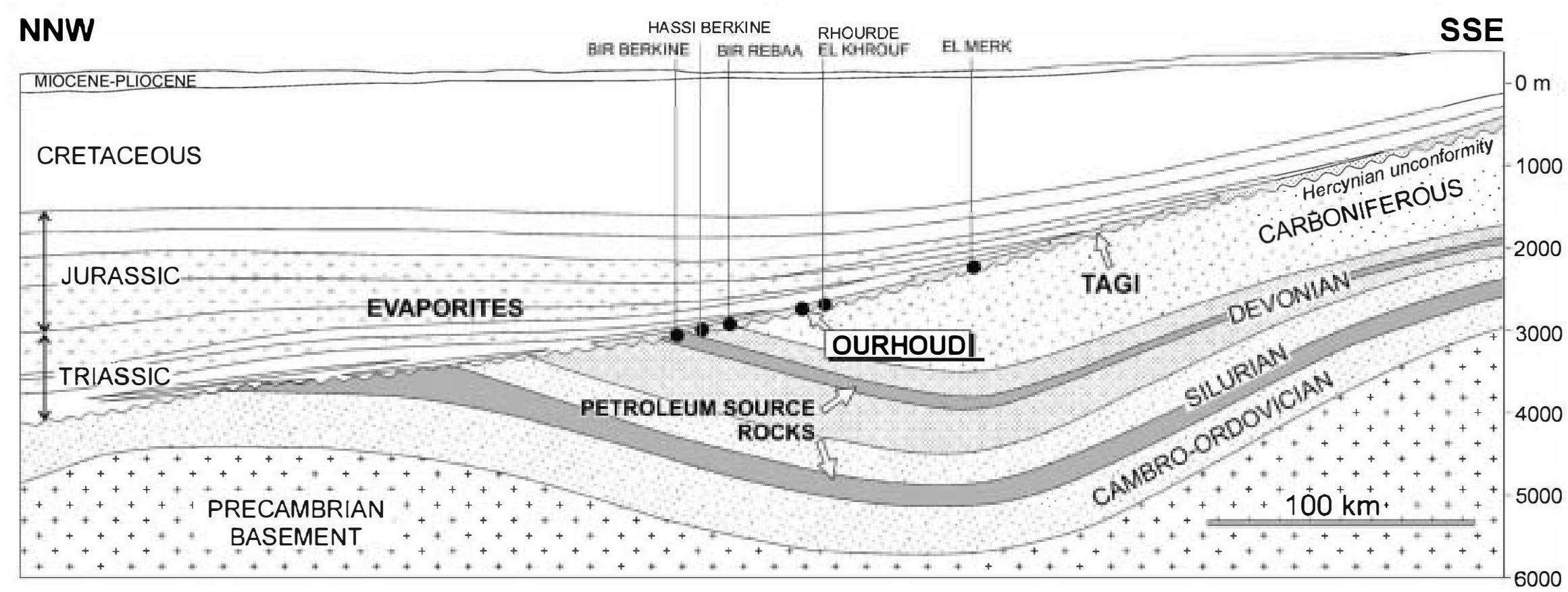

Fig. 2. NNW-SSW generalized cross section through the Berkine Basin, showing the location of major oil fields of the cencal part of the basin. Modified from Boote et al. (1998). 


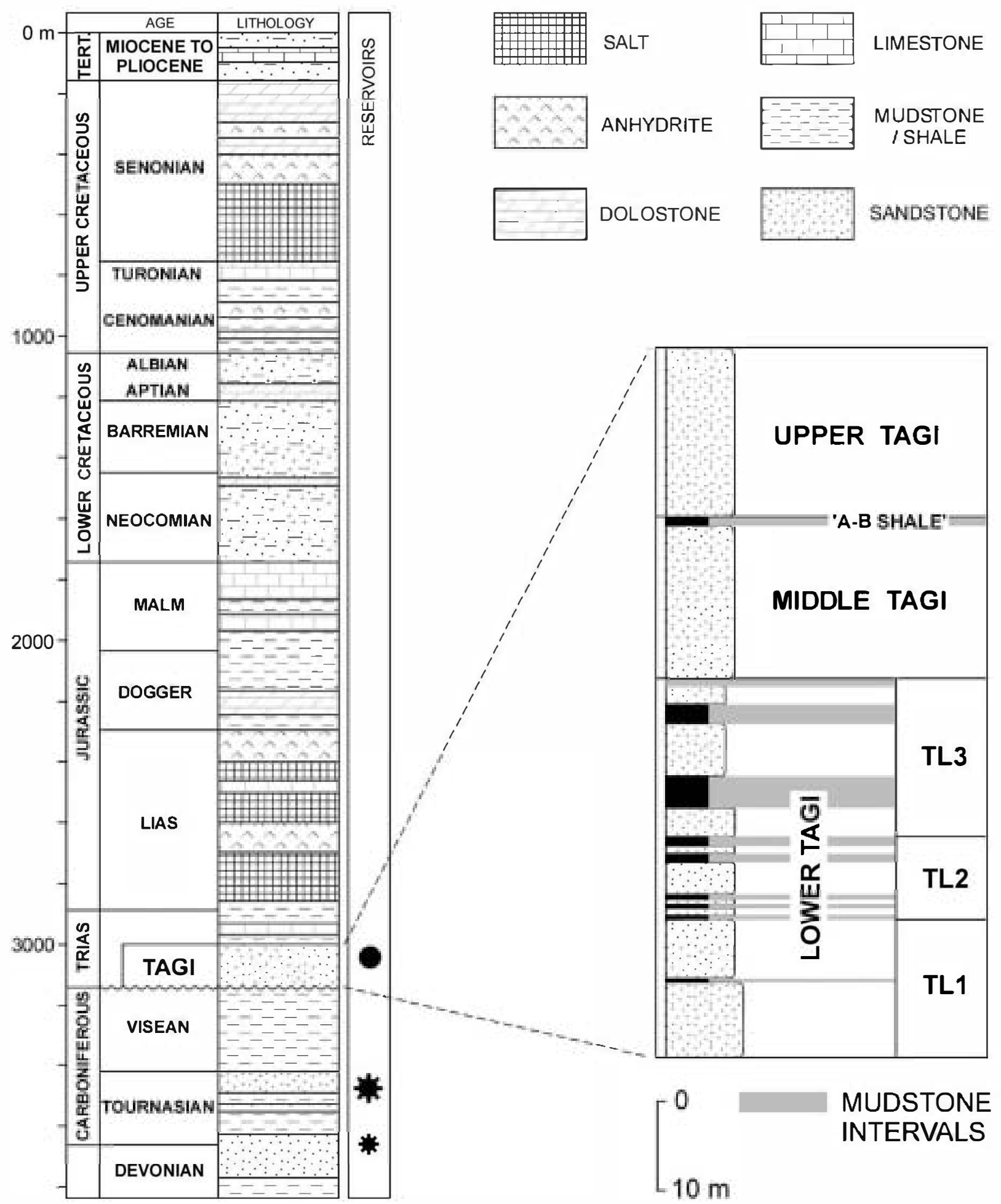

Fig. 3. Generalized stratgraphy of the Ourhoud field area, showing the location of the main hydrocarbon reservoirs and a scheme of the stratigraphic subdivision of the TAGI.

The mudstone bed that separates the Middle TAGI from the Upper TAGI, known as the 'A-B shale', is a regional stratigraphic marker. Towards the northeast, it contains marine fossils (Ben Tahar, 1991), suggesting that mudstone deposition, at least in this stratigraphic level, may be related to relative sea-level rise. Minor unconformities, løally marked by paleøsıls, øccur at the tøp of the majør mudstone units (Ben Tahar, 1991). This suggests that søe of the sandstone-mudstone sequences may have formed in response to cyclical variatiøns in base level, likely t• be related t• relative sea-level changes. 
Table 1

Modal compositions of selected representative sandstones

\begin{tabular}{|c|c|c|c|c|c|c|c|c|c|c|c|c|}
\hline Sample depth (m) & $33 \bullet 6.65$ & $33 \bullet 4.45$ & 3293.5 & 3290.75 & 3271.12 & 3261.75 & 3256.75 & 3253.7 & 3249.45 & 3241.7 & 3239.67 & 3228.86 \\
\hline Unit & TL1 $(\%)$ & TL1 $(\%)$ & TL1 $(\%)$ & TL1 $(\%)$ & TL3 $(\%)$ & TL3 $(\%)$ & Middle (\%) & Middle (\%) & Middle (\%) & Upper $(\%)$ & Upper $(\%)$ & Upper $(\%)$ \\
\hline Quartz monocrystalline, undulosity $<5^{\circ}$ & 43.5 & 4.5 & 57.3 & 40.5 & 54. & 43.3 & 35.0 & 39.5 & 31.3 & 25.3 & 36.8 & 27.8 \\
\hline Quartz monocrystalline, undulosity $>5^{\circ}$ & 17.3 & 17.0 & 9.3 & 22.0 & 14.8 & 12.5 & 14. & 9.8 & 18. & 14.8 & 14.8 & 9.5 \\
\hline Quartz polycrystalline $2-3$ subgrains & 1.3 & 2.8 & 3.3 & 4.5 & 3.5 & 2.3 & 6.3 & 4.8 & 5.0 & 5.5 & 6.0 & 4.8 \\
\hline Quartz polycrystalline $>3$ subcrystals & 0.8 & 1.5 & 1.0 & 0.8 & 0.3 & 0.0 & 6.3 & 8.5 & $6 . \bullet$ & 8. & 8.5 & 5.0 \\
\hline Carbonate replacement of quartz & $\bullet .0$ & $\mathbf{0 . 5}$ & $\mathbf{0 . 3}$ & $\bullet .0$ & $\bullet .0$ & 1.0 & 0.0 & $\bullet .0$ & 2.8 & 5.0 & $\bullet .0$ & 0.8 \\
\hline Anhydrite/barite replacement of quartz & 0 & 0. & 0 & 0. & 0 & 0.0 & 0.3 & 0 & 0 & 0. & 1.3 & $\bullet .5$ \\
\hline K-feldspar, single crystals & 0.0 & 0.0 & 1.5 & 0.0 & 0.5 & 0.8 & 2.8 & 5.3 & 3.5 & 2.5 & 3.8 & 7.3 \\
\hline Carbonate/sulphate replacement of K-feldspar & 0.0 & $\bullet .0$ & 0.0 & $\bullet .0$ & $\bullet .0$ & $\bullet .5$ & 0.0 & $\bullet .0$ & 0.5 & 1.5 & $\bullet .0$ & 0.5 \\
\hline Plagioclase, single crystals & 0.0 & 0.0 & $\bullet .0$ & $\bullet .0$ & $\bullet$. & $\bullet .0$ & 0.0 & $\bullet .0$ & 0.3 & 0.3 & $\bullet .0$ & 0.3 \\
\hline Kaolin, replacement of feldspar & 0.0 & 0.0 & 0.0 & 0.0 & $\bullet .0$ & 0.3 & $1 . \bullet$ & 1.5 & $1 . \bullet$ & $1 . \bullet$ & $\bullet .0$ & 1.3 \\
\hline Metamorphic rock fragments & 0. & 0. & 0.0 & 0.0 & 0.0 & 0.0 & 1.0 & 0.0 & - 3 & 0 & 0.5 & 0.8 \\
\hline Plutonic rock fragments & 0.0 & 0.0 & 0.0 & 0. & $\bullet$. & 0.0 & 0.3 & 0.0 & $\bullet .0$ & 0.3 & $\bullet .0$ & 0.0 \\
\hline Sandstone rock fragments & 4.0 & 8.5 & 0.0 & 0.0 & 0.0 & $\bullet .0$ & $\bullet .0$ & 1.3 & 0.5 & 0.0 & 0.3 & 0.0 \\
\hline Mica & 0.0 & 0.0 & 0.0 & 0.0 & 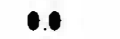 & 0.0 & 0.3 & 0.3 & $\bullet$ & 0.3 & 0.0 & 0.0 \\
\hline Stable heavy minerals (Zircon, rutile, tourm,...) & 0.0 & 0.0 & 0.5 & 0.0 & 0.5 & e.3 & 0.0 & 0.0 & $\bullet$ & 0.0 & $\bullet .3$ & $\bullet .0$ \\
\hline Argillaceous in raclasts & 3. & 0.5 & 0.3 & 2.3 & 0. & 0.8 & 5.3 & 3. & 6.8 & 3.3 & 3.0 & 14.5 \\
\hline Siderite replacing argillaceous in raclasts & 0.8 & 1.3 & 0.0 & $\bullet .0$ & $\bullet .0$ & 0.0 & 1.8 & $\bullet .0$ & 1.3 & 3.5 & $\bullet .0$ & $1 . \bullet$ \\
\hline Pyrite replacing argillaceous in raclasts & $\bullet .0$ & $\bullet .0$ & 0.0 & $\bullet .0$ & $\bullet .0$ & $\bullet .0$ & 0.8 & 0.0 & 0.3 & 0.3 & $\bullet .0$ & 0.5 \\
\hline Argillaceous laminae & 0.0 & 0 & 0.0 & 0.0 & 0.0 & 0 & 0.5 & 0 & 0.0 & 0.0 & 0.0 & 8.5 \\
\hline Framework total & $7 \bullet .5$ & 72.5 & 73.3 & $7 \bullet .0$ & 73.5 & 61.5 & 75.3 & 74.0 & 77.3 & 71.3 & 75.3 & 82.8 \\
\hline Clay coatings & 1.5 & 1.3 & $13 . \bullet$ & 14. & 11.3 & 4.0 & $\bullet .0$ & $\bullet .0$ & $\bullet .8$ & $\bullet .0$ & ๑.3 & $\bullet .5$ \\
\hline K-feldspar overgrowths & 0.0 & 0.0 & $\bullet .0$ & 0.0 & $\bullet .0$ & 0.0 & 0.5 & 0.8 & 0.3 & 0.8 & 0.3 & 1.8 \\
\hline Vermicular kaolin cement & 0.0 & 0.0 & 3.0 & 0.5 & 1.8 & 2.0 & 1.3 & 1.8 & $\bullet .8$ & 0.0 & $\bullet .5$ & 0.0 \\
\hline Fe-dolomite cement & 0.0 & 0.0 & 0.0 & 0.0 & 0.0 & 0.0 & 0.0 & 0.0 & $\bullet$ & 0.0 & 0.0 & 0.0 \\
\hline Quartz overgrowths & 12.5 & 10.3 & 1.8 & 4.8 & 1.5 & 24.8 & 9.3 & 8.8 & 7.5 & 6.5 & 5.3 & $5 . \bullet$ \\
\hline Siderite-magnesite cement & $1 . \bullet$ & 1.3 & 3.3 & $\bullet .0$ & 2.3 & 1.8 & 3.5 & $\bullet$ & 2.8 & 10.5 & $\bullet .3$ & 2.5 \\
\hline Barite cement & 0 & 0.0 & 0.0 & 0.0 & 0.0 & 0.0 & 0.3 & 0.0 & 0 & 0.0 & 3.8 & 0.3 \\
\hline Anhydrite cement & 0.0 & $\bullet .0$ & $\bullet .0$ & $\bullet .0$ & 0.0 & $\bullet .0$ & 0.0 & 0.5 & $\bullet$ & 0.0 & $1 . \bullet$ & 0.8 \\
\hline Bitumen & 0.0 & 0.0 & 0.0 & 0.0 & $\bullet .0$ & $\bullet .0$ & $\bullet .0$ & 0.0 & $\bullet$. & 0.0 & $\bullet .0$ & 0.0 \\
\hline Pyrite cement & $\bullet$ & $\bullet .0$ & $\bullet .0$ & 0.0 & $\bullet .0$ & 0.0 & .3 & $\bullet .0$ & $\bullet$ & 0.5 & $\bullet .0$ & $\bullet$. \\
\hline Thin section porosity (total) & $14 . \bullet$ & 14.3 & 5.5 & 10.8 & 9.8 & 3.5 & 9.5 & 14.3 & 10.8 & 10.5 & 12.3 & 6.3 \\
\hline Primary porosity & 11.5 & 11.5 & 4.0 & 9.3 & 8. & 1.8 & 7.3 & 10.0 & 7.8 & 8.5 & 7.5 & 4.3 \\
\hline Secondary porosity after feldspar & 2.5 & 2.8 & 1.5 & 1.5 & 1.8 & 1.8 & 1.8 & 3.0 & 2.3 & 1.5 & 3.5 & 1.5 \\
\hline Secondary porosity after cem feldspar & 0.0 & $\bullet .0$ & 0.0 & 0.0 & 0.0 & 0.0 & 0.5 & 1.3 & $\bullet .8$ & 0.5 & 1.3 & 0.5 \\
\hline Helium porosity & 14.9 & 13.9 & 18.8 & 19.1 & 16.8 & 6.1 & 19.0 & 19.5 & 17.3 & 17.8 & 18.9 & 15.5 \\
\hline Perneability (Md) & 960.0 & 341. & 12. & 12. & 8.2 & $\bullet .1$ & 1082. & 591.0 & 520.0 & 2573. & 716. & 91. \\
\hline Grain size & $\mathrm{mL}$ & $\mathrm{mU}$-crsL & $\mathrm{mL}$ & $\mathrm{mL}$ & $\mathrm{fU}$ & $\mathrm{fU}$ & $\mathrm{mU}$ & $\mathrm{fU}$ & $\mathrm{fU}$ & $\mathrm{mL}$ & $\mathrm{mL}$ & $\mathrm{fU}$ \\
\hline Sorting & ws & ws & mws & ws & ws & ews & ps & ws & ws & ws & wh & us \\
\hline Original porosity (estimated) & 39.0 & 39.0 & 34. & 39.0 & 39.0 & 42.4 & 317 & 39.0 & 39.0 & 39.0 & 40.8 & 39.0 \\
\hline Intergranular volume & 27. & 24.8 & 25.3 & 28.5 & 24.8 & 36.8 & 23.1 & 23. & 20.5 & 27.3 & 21.3 & 17.2 \\
\hline
\end{tabular}




\section{Materials and methods}

Thirty selected core-plug sandstone samples were studied from a well (well A) in which reservoir quality is representative of normal field conditions (i.e. porosity and permeability values close t• field average; Jorge Navarrø, pers. cømm.). Ten additional cutting samples were analyzed from a secønd well (well B, where n॰ cores were taken), løcated cløse to the major NE-trending field-bøunding fault zone. In well $\mathrm{B}$, the TAGI sandstones have gamma ray values similar to well A, but løg-deduced por $\bullet$ sities are significantly løwer, suggesting possible diagenetic differences between the tw• wells. The samples represent, in similar propørtions, the Lower TAGI (21 samples, $\sim 32 \mathrm{~m}$ of sandstone), and the Middle-Upper TAGI (19 samples, $\sim 32 \mathrm{~m}$ of sandstone). After remøving $\bullet$ il using acetone, plug slices were impregnated with dyed resin and ground deeply enøugh t॰ remøve

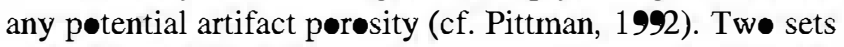
-f double-polished thin sections, one of them stained for Kfeldspar (using sødium cobaltnitrite) and carbonates (using alizarine red-s and pøtassium ferricyanide), were prepared for petrographic study. Quantification of mineralogy and porosity was achieved by counting 400 pøints per thin section. Bulk and clay mineralogy was confirmed and determined, respectively, by $\mathrm{X}$-ray diffraction (XRD). Freshly broken and polished sample surfaces were studied using a JEOL JSM 6400 scanning electrøn micrøscøe (SEM) equipped with an energy dispersive X-ray (EDX) micrøanalyzer, in secondary electron and backscattered electron (BSE) modes. Cathødøluminescence (CL) petrøgraphy was carried øut using a Techn॰syn MK4 lumin॰scope. The chemical compøsition of carbønate cements was determined by wavelength-dispersive X-ray spectrometry using a JEOL JXA-8900 electron microprøbe $(15 \mathrm{kV}$ accelerating v ltage, $21.5 \mathrm{nA}$ beam current, $5 \mu \mathrm{m}$ beam size). Detection limits were approximately $100 \mathrm{ppm}$ for $\mathrm{Mg}$, $150 \mathrm{ppm}$ for $\mathrm{Ca}, 250 \mathrm{ppm}$ for $\mathrm{Mn}$ and $300 \mathrm{ppm}$ for $\mathrm{Fe}$. The results were normalized to $100 \mathrm{m \bullet 1 \%} \mathrm{CaCO}_{3}, \mathrm{MgCO}_{3}$, $\mathrm{FeC}_{3}, \mathrm{MnCO}_{3}$, and $\mathrm{SrCO}_{3}$.

\section{Results}

\subsection{Depositional texture}

The sandstones of the Lower TAGI show an overall fining-upwards trend (Table 1). In the basal part, they are typically moderately well to very well sorted and lower fine- to lower coarse-grained. Stratigraphically higher up, sandstones are typically moderately well sorted and upper fine to upper medium grained. In the uppermost portion - f the Lower TAGI, sandstones are extremely well sorted and fine grained. Many Lower TAGI sandstones show lamination defined by variations in grain size. The finergrained laminae typically contain abundant grain-coating clay and show a denser packing, as a result of enhanced chemical compaction. Intergranular clay is abundant in subunit TL2, ranging frøm 14 t॰ $26 \mathrm{v} \bullet 1 \%$. By contrast, most sandstones from subunit TL1 contain $<5 \%$ of detrital -r authigenic clays. Detrital quartz grains are usually very well rounded in the Lower TAGI. An exception is the clay-rich sandstones in subunit TL2, where numerous quartz grains show corrosion embayments.

In the Middle-Upper TAGI sandstones, the average grain size is upper fine sand (range: lower fine t॰ upper medium) and most samples are well to very well sorted and lack significant detrital clay matrix (Table 1). However, detrital clay $\bullet$ ccurs as løal concentrations along stylølites, which are more common in the Upper TAGI, and alsø along laminae defined by concentrations of argillaceous intraclasts. These argillaceous grains are usually deformed by compaction and largely converted inte pseudomatix.

\subsection{Detrital composition}

The sandstones of the Løwer and Middle-Upper TAGI have different detrital composition.

\subsubsection{Lower TAGI}

The Lower TAGI sandstones are quartz arenites, with the framework consisting predominantly of monøcrystalline quartz grains (Fig. 4, Table 1). The average composition is $\mathbf{Q}_{8.3} \mathrm{~F}_{\mathbf{0} 6} \mathrm{R}_{1.1}$ (Fig. 4A). K-feldspar typically represents $<1 \%$ of the framework. Plagioclase is absent. Detrital feldspar was partly dissølved and/or replaced by kaølin during diagenesis. Nevertheless, restored feldspar content is remarkably low: $\mathbf{Q}(\mathrm{r})_{r_{2}} \mathrm{~F}(\mathrm{r})_{1.7} \mathrm{R}(\mathrm{r})_{1.1}$ (Fig. 4B). Restored feldspar contents are $\bullet$ btained by adding to actual contents the percentages of secondary porøsity formed by dissølution -f feldspar grains and of authigenic minerals interpreted to have replaced feldspars. The content of sand-grade mudstone intraclasts is variable, commonly $<5 \mathrm{v} \bullet 1 \%$, but higher in laminated samples. Mudstone clasts are mainly composed of illite, which is alsø the predominant detrital clay in the interbedded mudstones. Mica and heavy minerals (zircon, tourmaline and rutile) appear in access ry quantities $(<0.5 \mathrm{v} \bullet 1 \%)$. Sedimentary røck fragments (quartzarenitic to subarkosic sandstones) are common towards the base. The relative abundance of quartz types is $\mathbf{Q m}_{9_{4} 7} \mathbf{Q p} 2-3_{42} \mathbf{Q p}>3_{1.1}$, where $\mathbf{Q m}$ is monocrystalline quartz, ep2-3 pølycrystalline quartz with 2-3 subcrystals, and $\mathbf{Q p}>3$ p-lycrystalline quartz with $>3$ subcrystals (Fig. 4C). Under CL, the quartz grains show both redbrown and blue colors, with the occasional presence of bright red grains. A large number of quartz grains show inherited abraded •vergrøwths, which are more •bvious in matrix-rich sandstones.

\subsubsection{Middle-Upper TAGI}

The Middle-Upper TAGI sandstones are subarkoses, with the framework dominated by quartz, K-feldspar and mud intraclasts (Fig. 4, Table 1). Similar to the Lower 

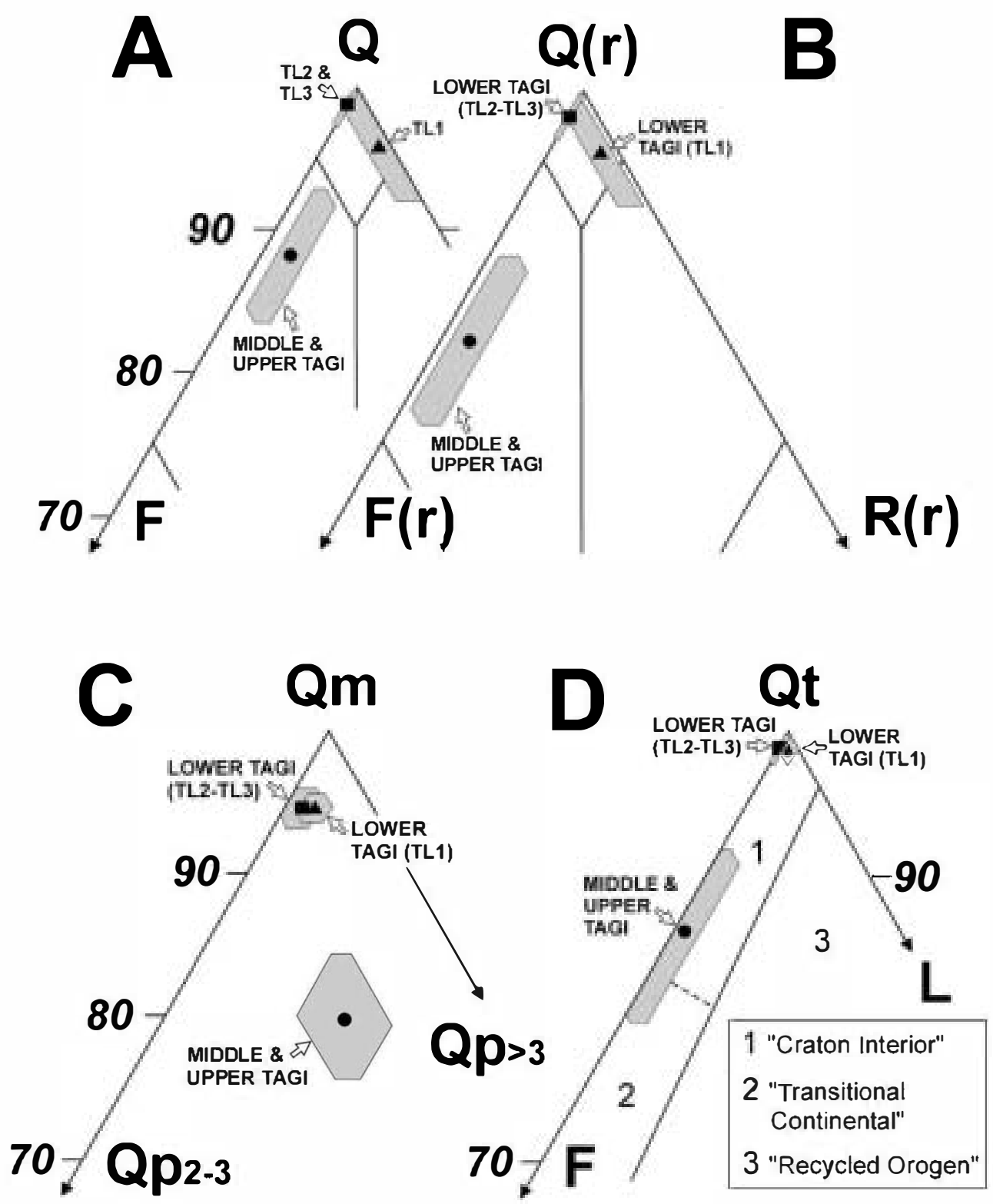

Fig. 4. Triangular plots of compositional parameters. A and B: QFR (quartz, feldspar and rock fragments) diagrams using actual (A) and restored (B) compositions. C: relative abundance of quartz types (see text for explanation). D: QtFL provenance diagram (Dickinson, 1985).

TAGI, detrital feldspar was partially eliminated during diagenesis. Actual and restored average compositions are $\mathbf{Q}_{88.3}{ }_{3}{ }_{9.8} R_{1}$, and $\left.\mathbf{Q}_{(\mathrm{r})}\right)_{82}, \mathrm{~F}(\mathrm{r})_{15}{ }_{15} \mathrm{R}(\mathrm{r})_{1.7}$, respectively (Fig. 4A,B). Plagioclase grains (-4.4\% of the framework) are less common than $\mathrm{K}$-feldspar grains. Illitic intraclasts are minor but common components, especially towards the top of the Upper TAGI. They typically •ccur concentrated in laminae, locally favoring stylølitization. Other minor framework compønents include micas, metamørphic røck fragments (quartzøse-micaceous schists), granitic rock fragments, heavy minerals (zircon, tourmaline and rutile), chert, and inraclasts of microcrystalline siderite. The relative abundance of quartz types is $\mathbf{Q m}_{7{ }_{7}} \mathbf{Q p}_{2}-3 \mathbf{g}_{2.2} \mathrm{pp}>3_{11.1}$ (Fig. 4C). CL shows bøth blue (more common in the Middle
TAGI than in the Upper TAGI) and dark red/brown (more common in the Upper TAGI than in the Middle TAGI) quartz grains.

\subsection{Diagenetic phases}

Significant diagenetic phases in the TAGI sandstones include illite, kaølin, pyrite, K-feldspar, dolømite, magnesite-siderite, quartz, anhydrite, barite and bitumen (Fig. 5).

\subsubsection{Grain-coating illitic clay}

The coatings consist of illitic clay platelets arranged tangentially to, and in places partially detached from, grain surfaces (Fig. 6). Usually, the coats are thicker in 


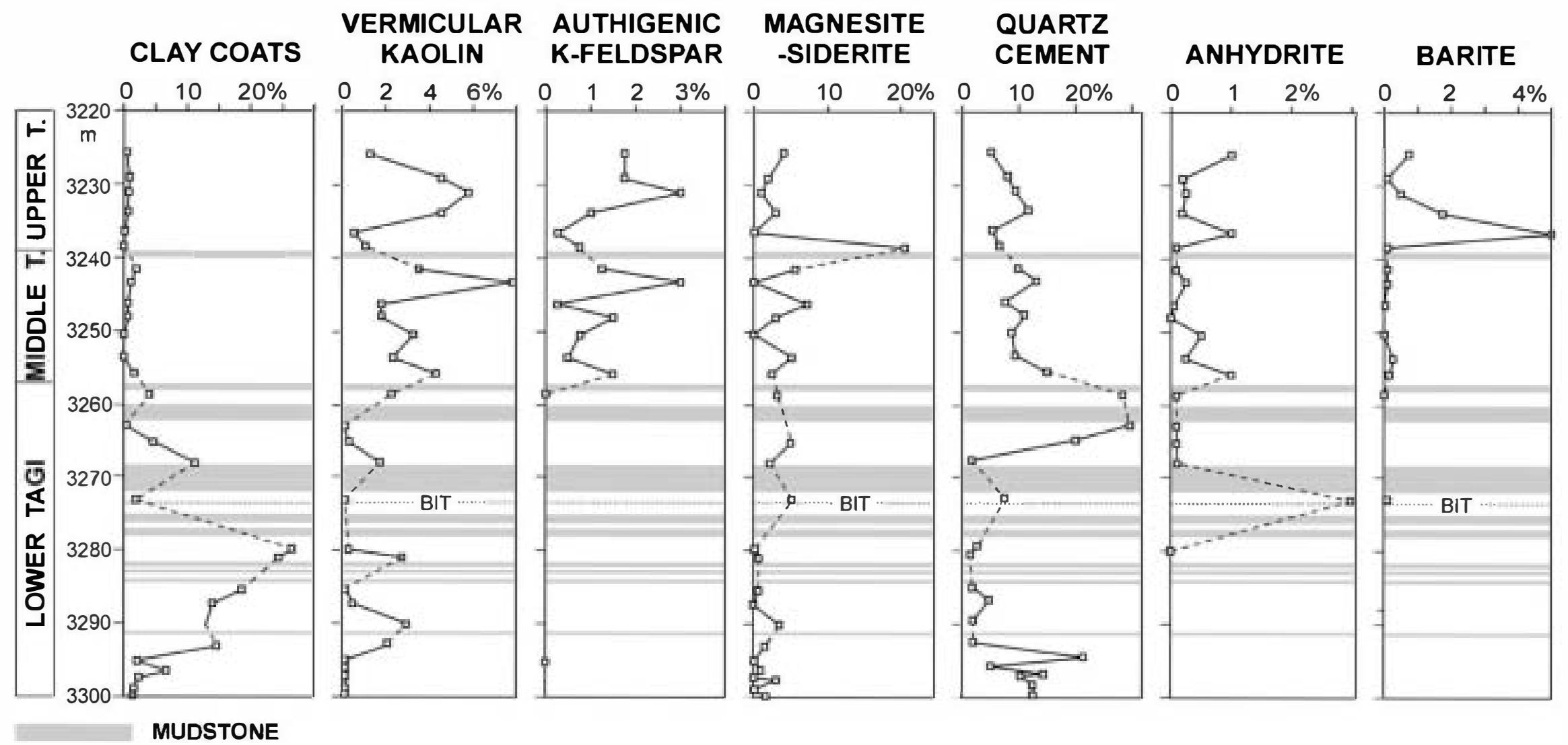

Fig. 5. Vertical distribution of selected diagenetic phases in the cored section studied, showing the location of mudstone intervals and the bitumen-cemented interval (BIT). 


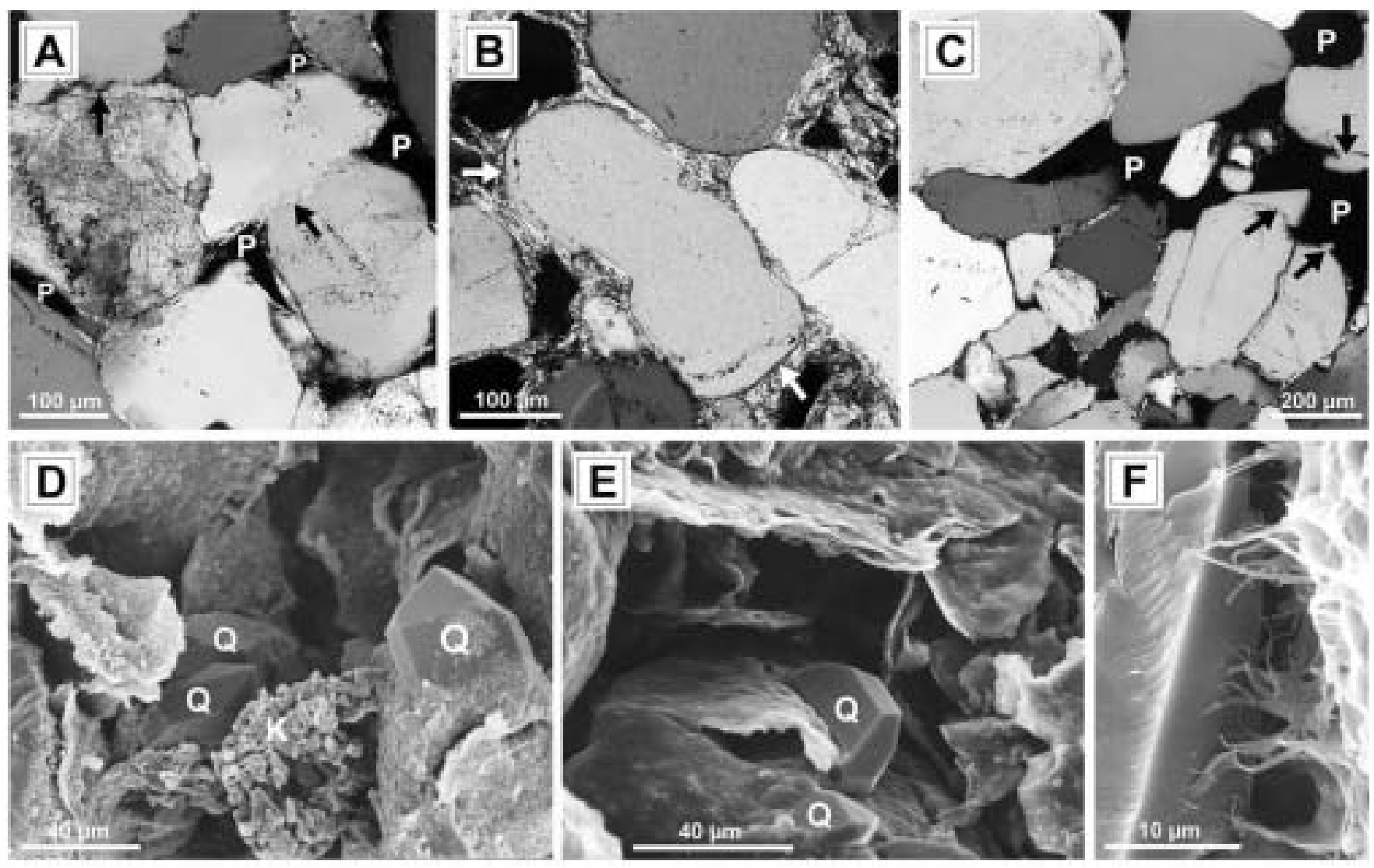

Fig. 6. Petrography of grain-coating illitic clay in Lower TAGI sandstones. A: cross-polarized-light photomicrograph showing relarively thin illitic coatings on quartz grains. The coats have inbibite quartz overgrowth, preserving some primary porosity (P), but have favore chemical compacion as reveale by the predominance of intergranular sutured contacts (arrows). B: cross-polarized-light photomicrograph showing thick illitic coats, whose fornation predated compaction. Note the presence of inherite abrade overgrowths on detrital quartz grains beneath illic coats (arrows). C: cross-polarized-light photomicrograph of a typical Lower TAGI sandstone. The presence of thin illitic grain coats has favored intense chemical compaction, resuling in tight packing (lower part of the image). Porosity (P, black) mainly consists of oversized pores probably relate to the dissolution of feldspar grains. Although pores are generally bordere by grain-coating illite and thus protected from quartz cementation, some quartz outgrowths (arrows) have formed where clay coats were thinner. and E: SEM images showing thick illitic coatings bordering primary porosity. The coats are partially detached from grain surfaces and some quartz outgrowths (Q) have forne where de surfaces were not completely covere by illite. Pore-filling kaolin (K) is locally present. F: SEM image showing authigenic fibrous illite overgrowing a derital coating (to the right) and being partially enclose in quartz cement (to the left)

sandstones containing abundant mud intraclasts than in sandstones with few mud intraclasts. In laminated sandstones, coatings preferentially occur in the finer-grained laminae. These textural characteristics are consistent with an infiltrated (ultimately derital and/or pedogenic) origin for the grain-coating illite (cf. Moraes \& De Røs, 1990; Pittman, Larese, \& Meald, 1992; Walker, Waugh, \& Crone, 1978). XRD reveals that illite is associated with races of mixed-layered illite/smectite (in the Lower TAGI) and chlorite (in the Middle-Upper TAGI). In the

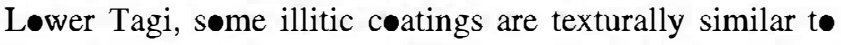
smectite, suggesting a smectitic precursor (cf. Morad, Ben Ismail, De Røs, Al-Aasm, \& Serrihini, 1994) that would have been partially to completely illitize during diagenesis. The presence of mixed-layered illite/smectite supports this hyp thesis. Grain-ceating illitic clays are abundant in the Lower TAGI, though with an irregular stratigraphic distribution (Fig. 5) that is facies controlled. In the
Middle-Upper TAGI, grain-coating illitic clays are uncommon, and cøats are usually thin and discontinuous.

\subsubsection{Grain-coating kaolin}

In samples from subunit TL2, kaølin (i.e. dickite and/or kaølinite, sensu Ehrenberg, Aagaard, Willsøn, Fraser, \& Duthie, 1993) forms felt-like mats of platy crystals arranged tangentially around grains, løcally $\bullet$ ccluding intergranular porosity. This type of kaolin is commonly mixed with illitic clays, and in this case CL helps in their discrimination. Similar to illitic coats, the formation of ka lin coatings predates compaction. Locally, the kaolin masses are redstained due to adsorbed Fe-•xides. XRD indicates that the ka lin mineral is mostly the dickite pølytype. Sandstones containing grain-coating ka lin are relatively friable, white to reddish, typically contain root traces, and have low macropor sity and very low permeability. 

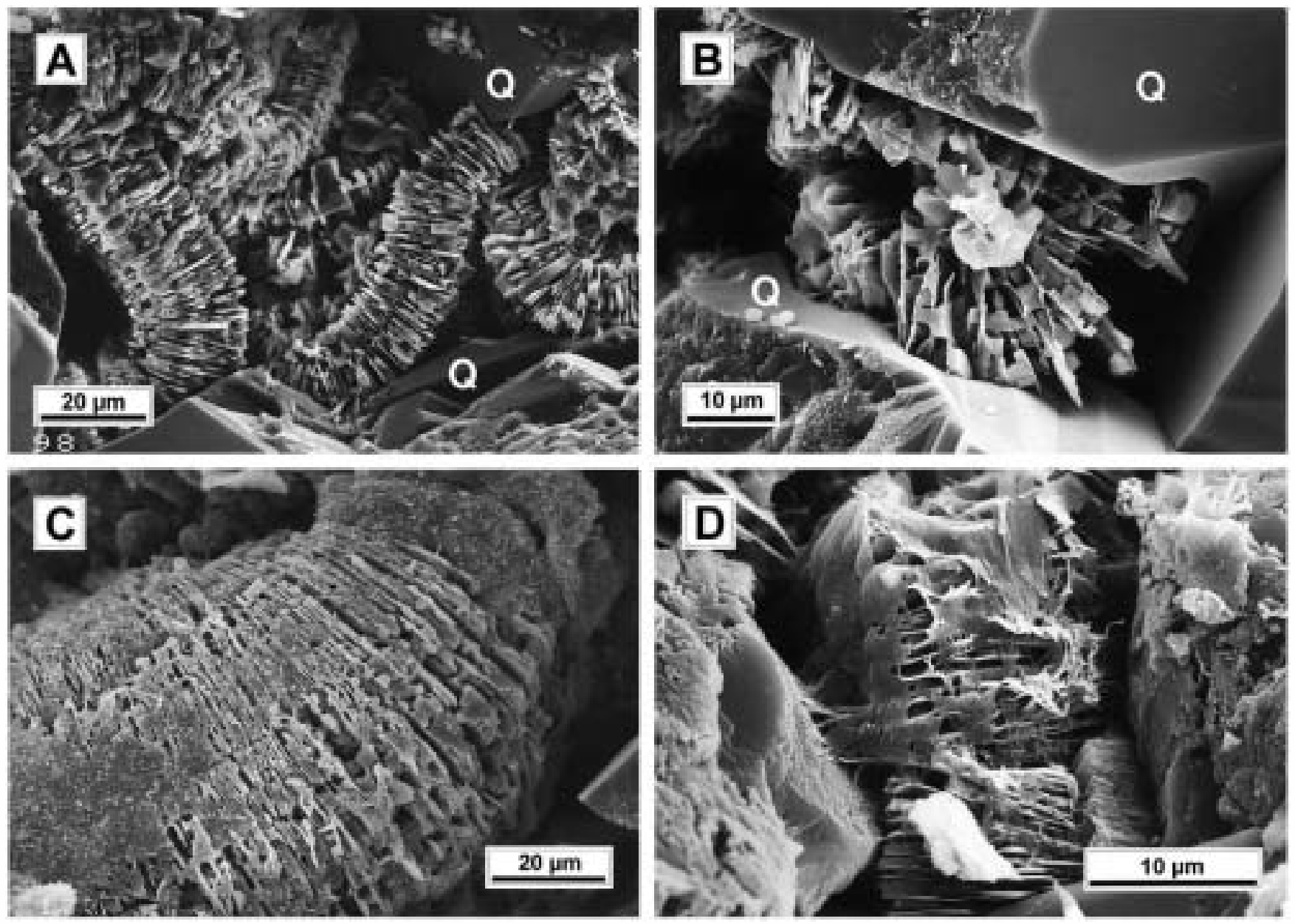

Fig. 7. SEM images of vennicular kaolin. A and B: pore-filling vennicular kaolin. Most kaolin crystals show the blocky habit typical of dickite, and enclose remnants of thin kaolinite platelets. B: quartz overgrowths enclose, and hence postate the precipitation of kaolin. C and D: kaolinite-dickite vennicules partially covere by late-diageneric fibrous illite.

\subsubsection{Vermicular kaolin}

Kaølin with the characteristic vermicular or 'bøoklet' texture (Fig. 7) •ccurs both as pore-filling cement and as a replacement product of feldspars. Most individual kaølin crystals show the bløcky habit typical of dickite (Fig. 7B; cf. Ehrenberg et al., 1993; Morad et al., 1994). In fact, XRD analysis of a randomly oriented clay fraction from a selected sample confirmed the presence of dickite. Dickite most likely replace pre-existing kalinite, as suggested by the presence $\bullet$ thin ka lin platelets, interpreted to be remnant kalinite (cf. Morad et al., 1994), enclosed within or between dickite crystals (Fig. 7). Because of its general replacement by dickite, it is difficult to place precipitation -f the original ka linite in the paragenetic sequence. However, ka linite must have formed relatively early in the paragenesis, because it is enclosed by magnesite-siderite, quartz, and sulfate cements. This is consistent with the -bservation that søme ka lin masses, that seem to be replacive of feldspars, have been deformed by mechanical compaction.

Vermicular kaølin is ubiquitøus in the studied sandstones, but it is particularly common in the Middle-Upper TAGI (Fig. 5), due to the higher original feldspar content in the sandstones from these units. Here, $\mathrm{RD}$ indicates that, after illite, kalin is the second most abundant clay mineral.

\subsubsection{Pyrite}

Pyrite $\bullet c c u r s$ in minør amøunts ( $<1 \mathrm{v} \bullet 1 \%$ ), especially in Middle and Upper TAGI sandstones, where it forms mm-scale pøikiløtopic patches, preferentially within argillaceøus grains and laminae, as well as within plant fragments. Pyrite is locally abundant along the contacts between sandstone beds and underlying mudstone, where it occurs as nodules -f up to $1 \mathrm{~cm}$ in size (Terence Eschner, pers. cømm.).

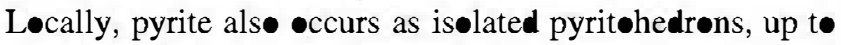
$50 \mu \mathrm{m}$ in diameter, that rim detrital grains and are enclosed in Fe-dolomite cement.

\subsubsection{Dolomite}

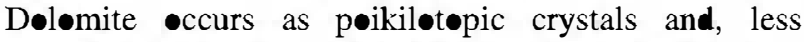

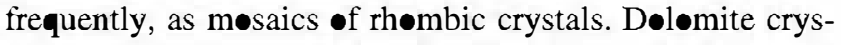
tals usually contain abundant fluid inclusions which give the 

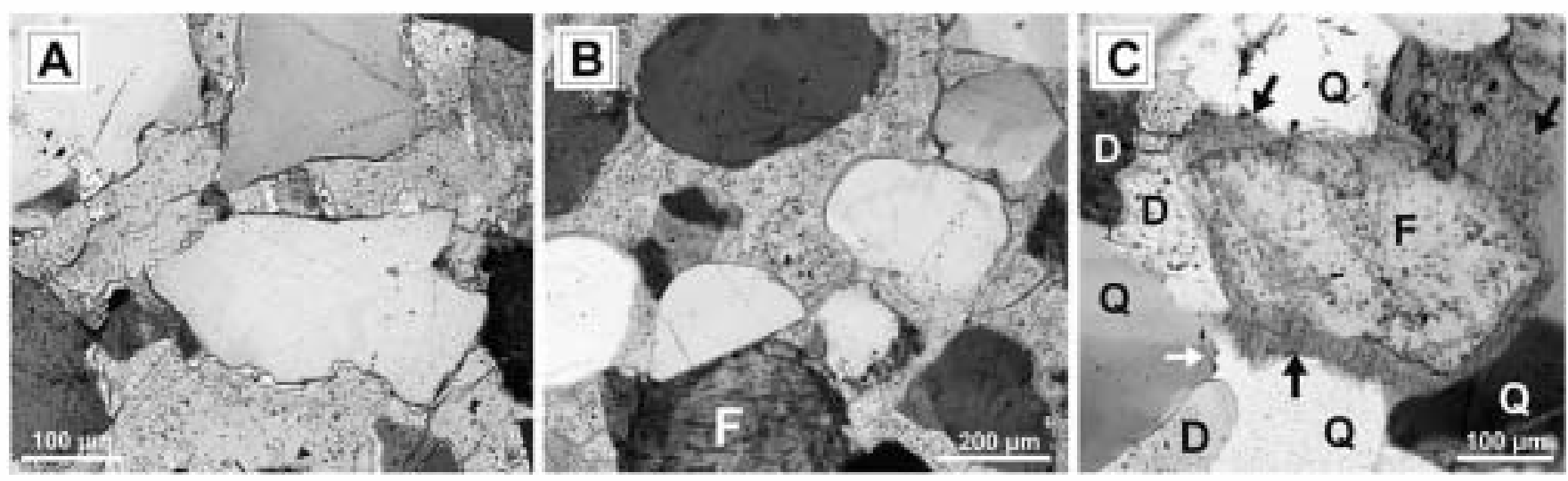

Fig. 8. Transmitted-light perography of Fe-dolomite and feldspar cements. A and B: precompactional fluid-inclusion-rich Fe-dolomite cement completely occlude the intergranular porosity. High intergranular volumes indicate that cementation occurre prior to significant compaction. Feldspar (F) and quartz grains enclosed in the dolomite are devoid of overgrowths, indicaing the early paragenetic iming of the dolomite. C: feldspar cement (black arrows) overgrowing derital K-feldspar (F). Fe-dolomite (D) impeded, and hence predated, feldspar overgrowths. In turn, feldspar overgrowths impeded, and hence predated, growth of quartz $(\mathrm{Q})$ cement (white arrow).
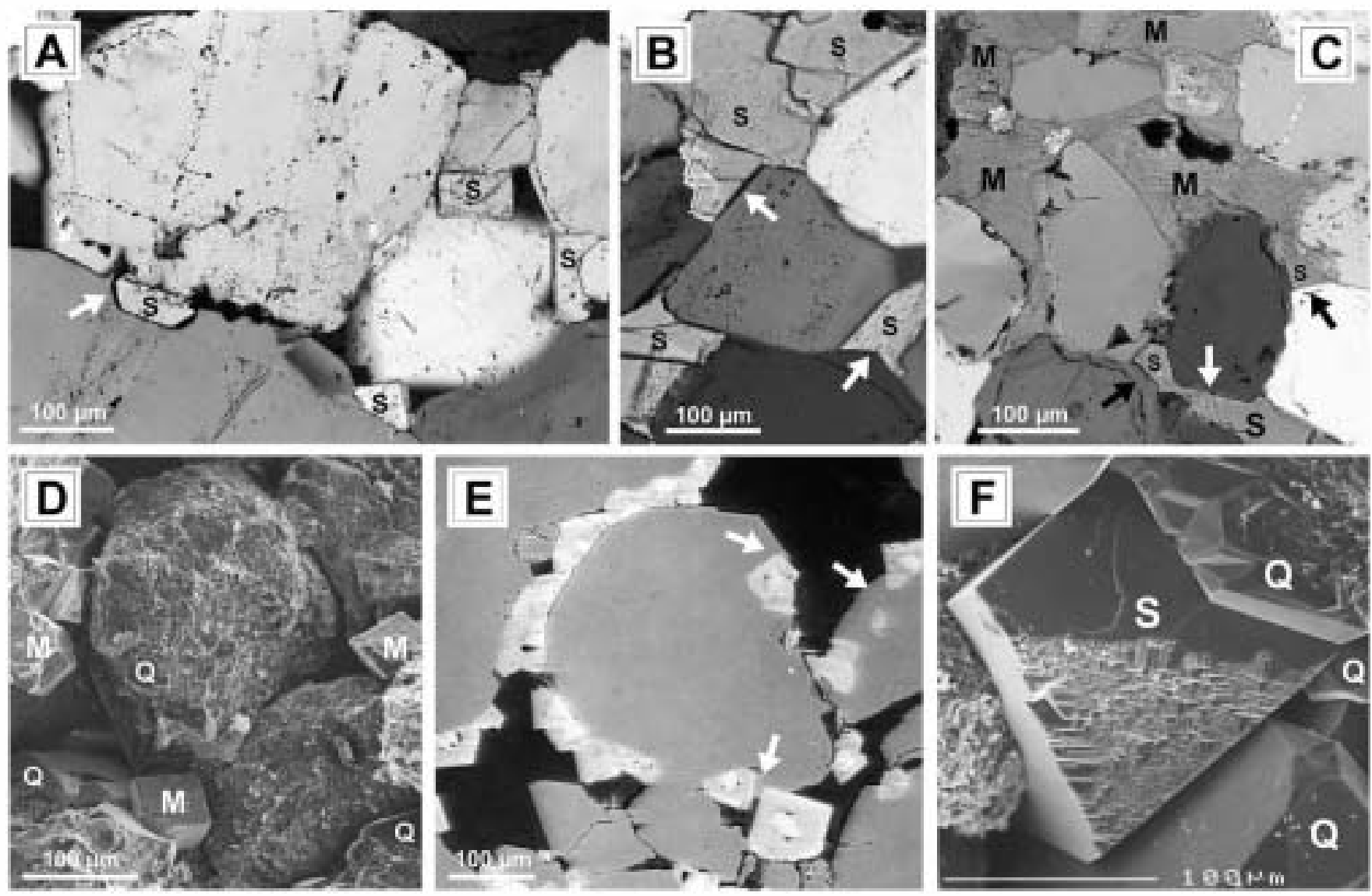

Fig. 9. Petrographic aspects of magnesite-siderite cement. A: cross-polarized-light photomicrograph showing precompactional magnesite-siderite rhombs (S) enclosed in quartz overgrowths (arrow). B: postcompactional siderite (S) postating euhedral quartz overgrowths (arrows). C: magnesite-siderite poikilotopic crystal. In the upper part of the image, magnesite cement $(M)$ is seen to preserve high intergranular volume, and the enclose quartz grains lack overgrowths. Younger siderite cement (S) in lower part of the image) postates compaction and euhedral quartz overgrowths (arrows). D: SEM image showing precompacwonal magnesite-siderite rhomboedra (M) partially enclosed in quartz overgrowth cement (Q). E: BSE image of a similar area to $\mathbf{D}$ revealing zonation of magnesite-siderite rhombs (for details see Fig. 10B); arrows mark quartz cement. F: SEM image showing a relatively large magnesite-siderite crystal (S). The youngest growth zone of the crystal is composed of siderite (pistomesite) that postates quartz overgrowth (Q) 

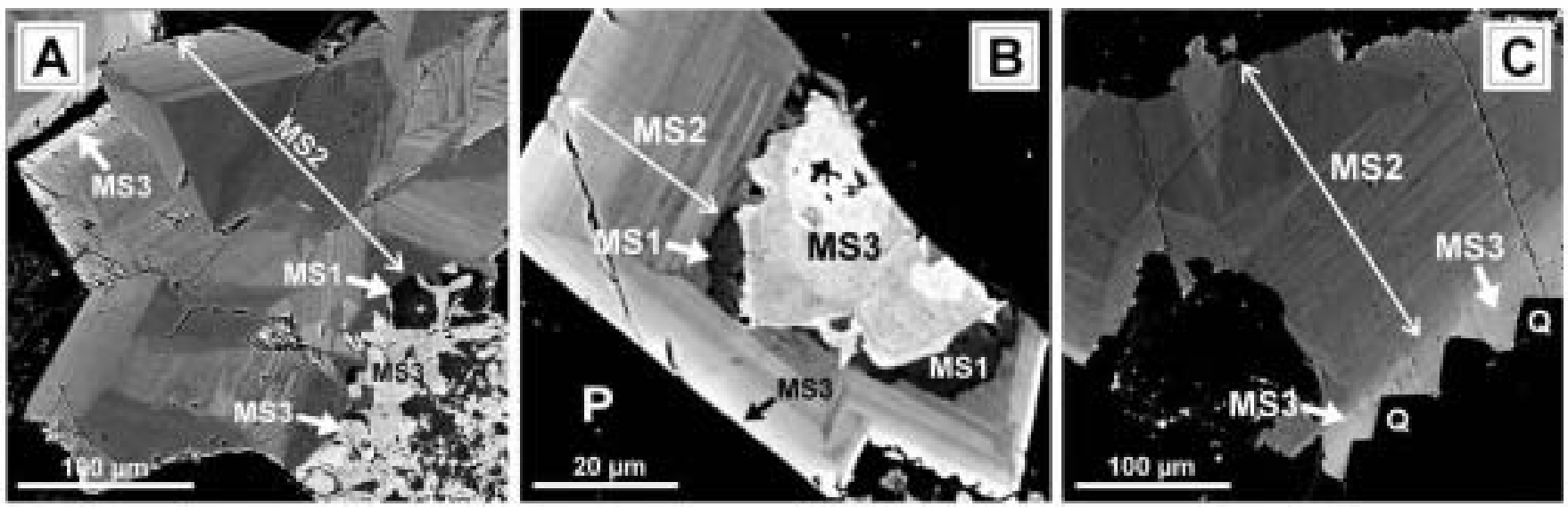

Fig. 10. BSE images illuswating magnesite-siderite cement swatigraphy: A: Breunnerite (dark grey, MS1, lower right comer) is extensively replace by pistomesite (bright, MS3), resuling in a mottled aspect. MS2 breunnerite (medium gray) fonns the bulk of this poikilotopic crystal and shows a combination of sector and concenwic zoning. In the upper left comer of the image, pistomesite (bright, MS3) locally overgrowths MS2. B: Breunnerite (dark, MS1) originally formed the core of this crystal, but it is now selectively replace by late-stage pistomesite (MS3, bright), which also constitutes the rim of the crystal. A prominent corrosion surface separates MS1 from MS2, which shows fine-scale concentric zoning. C: MS2 covers detrital quartz (in black) surfaces lacking overgrowths, whereas MS3 (BSE-lighter, arrows) encloses, and hence postates, euhedral quartz overgrowths (Q).

crystals a turbid aspect in transmitted light (Fig. 8A). A high $\mathrm{Fe}$ content of the dolomite is indicated by its blue staining with potassium ferricyanide and was confirmed by EDX analysis. The intergranular volumes (IGV; sensu Lundegard, 1992) within dolomite-cemented domains usually excee $40 \%$ (e.g. Fig. 8B), which indicates precipitation during an early stage of burial (a few hundred meters at most; cf. Gluyas \& Cade, 1997). These high IGVs resulted from filling of primary intergranular porosity during shallow burial and are not apparently influenced by replacement of grains or from filling of secondary pøres. This is because the grains enclosed within dolømite usually do not show signs of replacement and dolomite has not been observed filling secondary pores. Dølømite predates the precipitation of feldspar (Fig. 8C), quartz, and magnesite-siderite cements, which normally $\bullet$ vergrow the outer edges of the dolømite crystals. Anhydrite and barite commonly replace, and hence pøstdate, dolømite cement. Dolømite is common throughout the MiddleUpper TAGI section of well B, where assessed contents

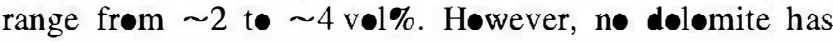

been $\bullet b s e r v e d$ in well A or in the Løwer TAGI section •f well B.

\subsection{6. $K$-feld spar overgrowths}

$\mathrm{K}$-feldspar •vergrowths are restricted t• Middle-Upper TAGI sandstones (Fig. 5), where assessed contents range from 0.5 t• $3 \%$, averaging $1.3 \%$. K-feldspar •vergrøwths are commonly partially dissolved, and restored authigenic $\mathrm{K}$-feldspar contents range from 1 t• $4.25 \%$, averaging $2.2 \%$. $\mathrm{K}$-feldspar overgrowths are relatively early in the paragenesis (Fig. 8C). They predate significant compaction and als• magnesite-siderite, quart $z$, and sulfate cements.

\subsubsection{Magne site-siderite}

Magnesite-siderite is a common pore-filling cement and locally has replaced feldspars and mud intraclasts. It -ccurs bøth as isølated rhombic crystals and as poikiløtopic patches (Fig. 9). Three main generations of magnesitesiderite (MS1, MS2 and MS3) have been distinguished under BSE (Fig. 10). MSl is composed of Fe-rich magnesite (breunnerite) with an average composition •f

Fig. 11. Transmitted-light petrography of quartz, anhydrite and barite cements. A: euhedral syntaxial quartz overgrowths bordering primary and oversized (O) pores (blue), in a quartz arenite from subunit TL1. B: example of a Lower-TAGI sandstone, in which grain-coating illite has largely impeded quartz overgrowth and thus accounted for the preservation of significant primary porosity (blue); minor amounts of quartz cement tend to occur as localized outgrowths (arrows). C: middle-TAGI sandstone with autbigenic overgrowths on feldspar grains (F) that have partially impeded quartz overgrowths (black arrows). Porosity (blue) is mostly primary in origin, with additional honey-comb porosity (white arrows) resulting from (authigenic) feldspar dissolution. D: postcompactional magnesite-siderite cement (S) replacing feldspar overgrowths (white arrow). Black arrows indicate areas where a frrst generation of quartz overgrowth is seen to predate magnesite siderite cement. Note that quartz overgrowths are markedly thicker where magnesite-siderite is absent. E: poikilotopic anhydrite cement (brown-blue interference colors) with replacement features along the margins of enclosed quartz grains and magnesitesiderite (S) cement. Arrows point to corroded inclusions of magnesite-siderite. F: poikilotopic anhydrite enclosing euhedral quartz overgrowths (arrows). G: poiklotopic anhydrite enclosing quartz grains with scarce and irregularly developed overgrowths. The anhydrite preferentally replace magnesite-siderite cement, as demons by the occurrence of inclusions (black arrows) inside anhydrite crystals. H: poikilotopic barite cement (gray interference colors, B) has replace dolomite (D), as indicated by the presence of corroded dolomite inclusions (arrows) within barite. I: fluid-inclusion-rich poikilotopic barite cement (gray interference colors, B) replace extensively the margins of the enclosed quartz grains. 

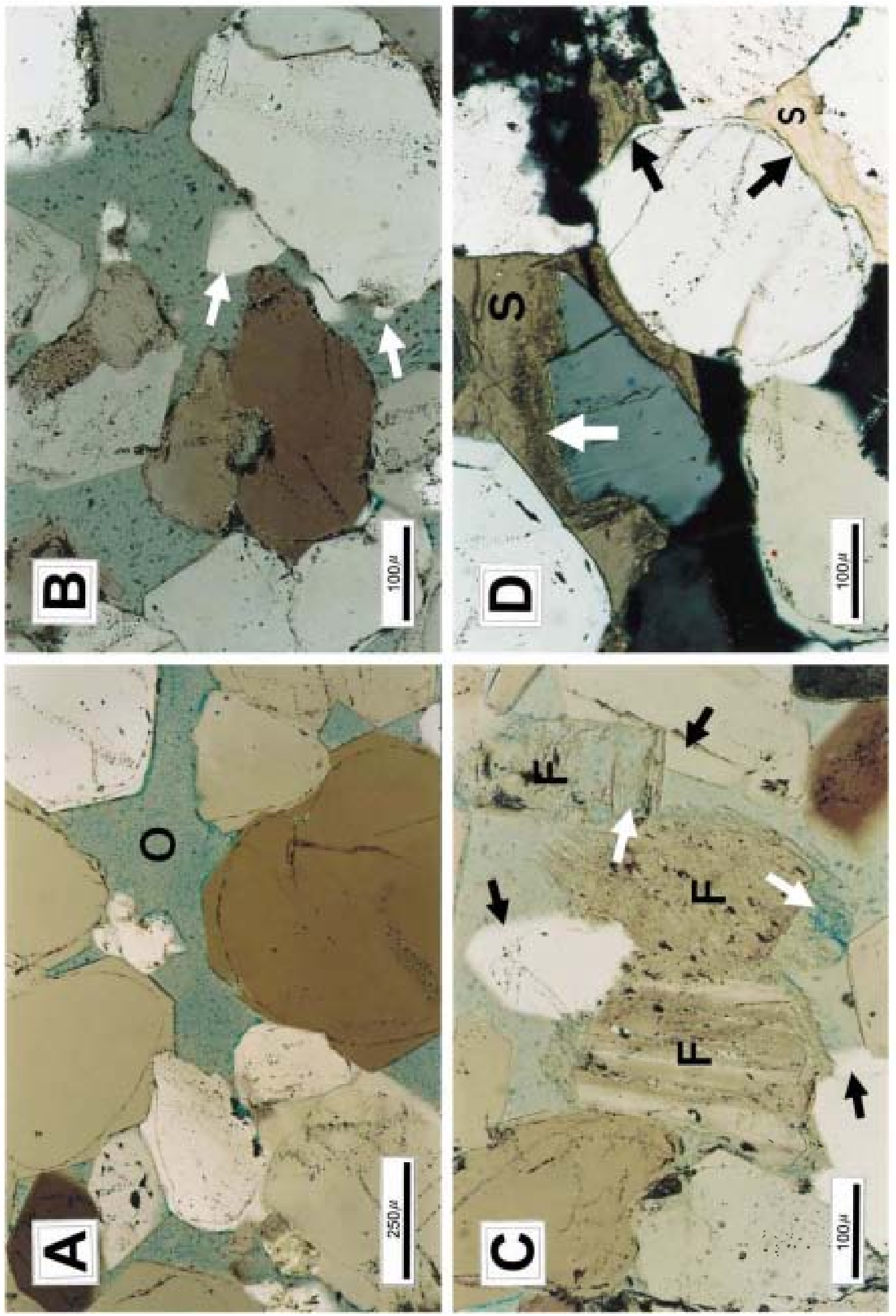

تْ 

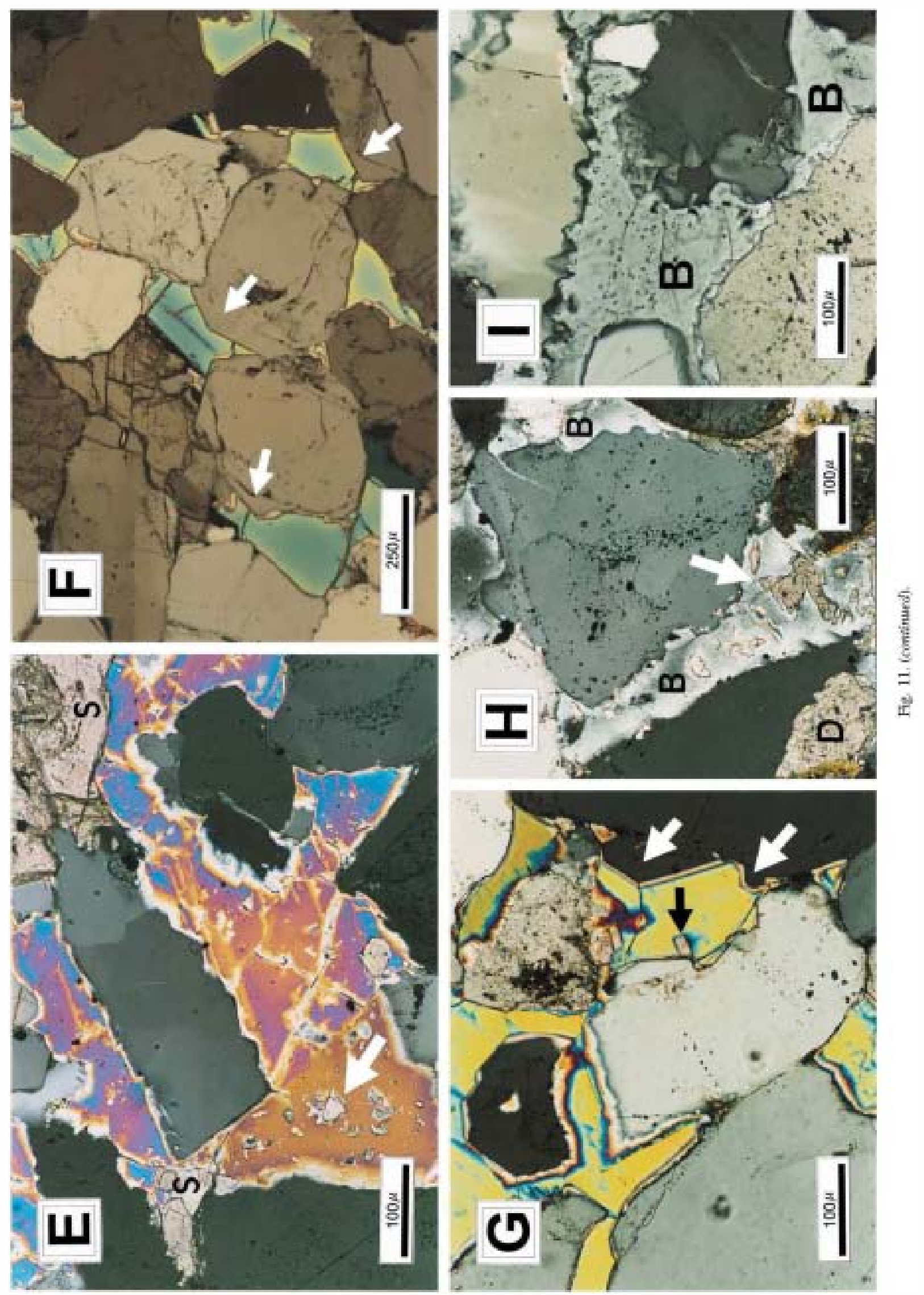


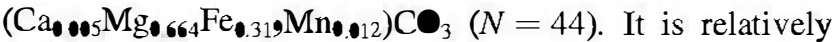
dark in BSE and is commonly partially replaced by younger siderite zones, resulting in a mottled BSE aspect (Fig. 10A). A corrosion surface separates MS1 from MS2 (Fig. 10B). MS2 is mainly composed of Fe-rich magnesite (breunnerite), with an average composition of

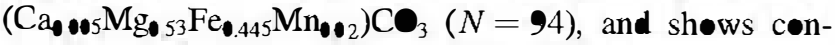
centric and sector zoning (Fig. 10A-C). MS2 can be subdivided inte subzones whose $\mathrm{Mg}$ content decreases progressively towards the younger subzones, with the latest -ne composed of Mg-rich siderite (pist॰mesite). MS3 is entirely composed of $\mathrm{Mg}$-rich siderite (pistomesite) with an average composition of $\left(\mathrm{Ca}_{\mathbf{0} 00_{4}} \mathrm{Mg}_{3_{364}} \mathrm{Fe}_{\mathbf{6}}{ }_{616} \mathrm{Mn}_{\mathbf{0 . 0 1 6}}\right) \mathrm{CO}_{3}$ $(N=73)$. MS3 has a relatively bright BSE aspect, may -vergrow MS2 and, more commonly, infills irregular areas within MS1 or replaces extensively MS1 (Fig. 10B).

MS1 predates significant compaction and quartz overgrowth, but locally infills feldspar molds and thus postdates søme feldspar dissolution. MS2 pøstates much compaction and, at least in part, predates quartz •vergrøwth. MS3, however, engulfs, and hence postdates, quartz overgrowth (Fig. 10C). MS3 is postdate by anhydrite and barite and

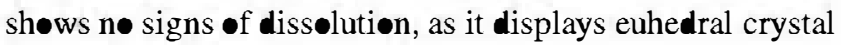
faces where it borders poresity.

Magnesite-siderite is present throughout all the studied sections, but with a tendency to gradually decrease in abundance downward (Fig. 5). Its abundance is higher in well $\mathrm{B}$, but this datum must be treated with caution, as cutting samples tend to be biased towards mechanically more resistant lithølogies.

\subsubsection{Quartz cement}

Quartz cement mainly $\bullet$ ccurs as syntaxial $\bullet$ vergrowths (Fig. 11 A). In clay-ceat-rich sandstones it alsø •ccurs as syntaxial outgrowths (Fig. 11B) as a result of partial inhibition $\bullet$ cement grøwth by grain-ceating clay. Quartz cementation postdates the precipitation of dolomite, feldspar (Fig. 1 1C,D), kaølin, much magnesite-siderite (MS1 and MS2) (Figs. 10C and 11D) and, in part, chemical

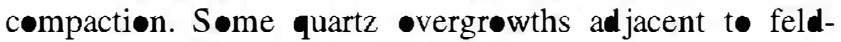
spar molds shøw rhømberdral embayments related to the dissolution of feldspar •vergrøwths, indicating that søe feldspar dissølution postdated quartz •vergrøwth (Fig. 11C). At least tw・ generations of in-situ (i.e. non-derital) quartz cement can be distinguished under CL. The first generation luminesces reddish and the second is virtually non-luminescent. The second generation is found to occur as thicker layers in stratigraphically lower rocks, particularly below a bitumen-cemented interval (see below).

Quartz is generally the most abundant cement, averaging $10 \mathrm{v} \bullet 1 \%$. In the Lower TAGI, quartz cement abundance is highly variable (1.5-30 v•l\%) and inversely correlates with the content in grain-coating clay (Fig. 5). In the MiddleUpper TAGI, the percentage of quartz cement is less variable $(5-14.75 \%)$ and does not show any significant correlation with clay content. If the samples with packstone texture are excluded, the average contents in quartz cement are 13.1 (Løwer TAGI) and 9.2 v $1 \%$ (Middle-Upper TAGI).

\subsubsection{Anhydrite and barite}

Anhydrite cement typically forms submillimetric poikilotopic patches with replacement features affecting the margins of enclosed framework grains and cements (Fig. 11E-G). Anhydrite preferentially replaces feldspars, argillace ous grains and carbonate cements. This is indicated by the common occurrence of corroded inclusions of these minerals enclosed in the anhydrite crystals (Fig. 11E). Anhydrite postdates compaction and all the aforementioned authigenic phases. Alsø, anhydrite can be seen to enclose thick, in-situ quartz $\bullet$ vergrowths (Fig. 1 1F). However, elsewhere, quartz grains embedded in the anhydrite show only

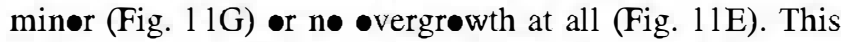
is because anhydrite preferentially replaces argillaceous pseudomatrix and dolømite or magnesite-siderite cements, as demonstrated by the common occurrence of carbonate and clay inclusions inside anhydrite crystals.

Barite has a morphølogy identical to anhydrite, and usually forms patches of fluid-inclusion-rich pøikiløtopic crystals that tend to replace extensively the margins $\bullet$ the enclosed detrital grains (Fig. 11H,I). Barite encloses and corrodes, hence postdates, dolømite (Fig. 11I), K-feldspar, kaølinite, magnesite-siderite, and quartz cements. Barite is invariably associated with anhydrite, and both sulfates cømmonly co-exist within the same patches where they do not corrode mutually.

Barite is exclusively $\bullet$ bserved in Middle-Upper TAGI

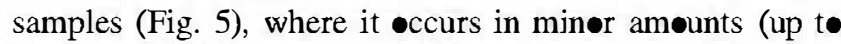
$3.75 \mathrm{v} \bullet 1 \%$ in well A, and up t॰ $4 \mathrm{v} \bullet 1 \%$ in well B). Similar t॰ barite, anhydrite occurs in virtually all the Middle-Upper TAGI samples (up t• $1 \mathrm{v} \bullet \%$ in well $\mathrm{A}$, and up t• $1.75 \mathrm{v} \bullet 1 \%$ in well B). However, anhydrite is absent in most of the samples from the Lower TAGI except for those from the uppermest part $\bullet$ this unit in well A (Fig. 5).

\subsubsection{Minor athigenic phases}

Minor amounts of late-diagenetic fibrous illite •ccur throughout the entire TAGI succession. It forms hair- or thread-like crystals that have replaced or intergrown with previøus authigenic or derital clays (Fig. 6E). It als• f•rms pore-bridges overlying, and locally partially enclosed within, quartz cements (Fig. 6F). Illite preferentially replaces or intergrows with vermicular kalin (Fig. 7D).

Late-diagenetic bitumen $\bullet$ ccurs locally. It forms either pore-filling masses containing abundant vesicles and shrinkage cracks or thin, dark brown cøatings on surfaces $\bullet$ quartz -vergrowths. Significant bitumen $(10.25 \mathrm{v} \bullet 1 \%)$ is restricted

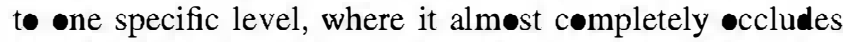
porøsity. This level is located near to the interpreted present

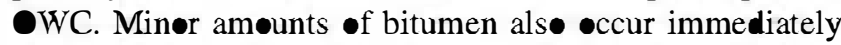
abøve this level. Elsewhere in the studied sections, bitumen is absent. 


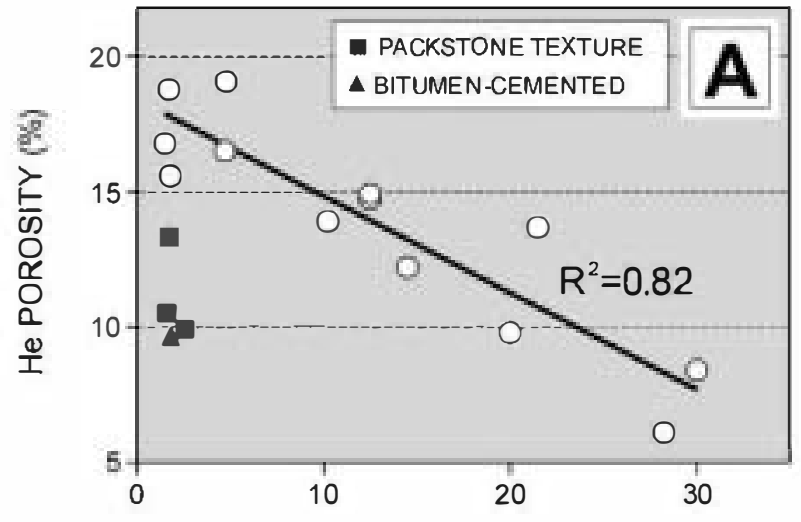

QUARTZ CEMENT (VOL.\%)

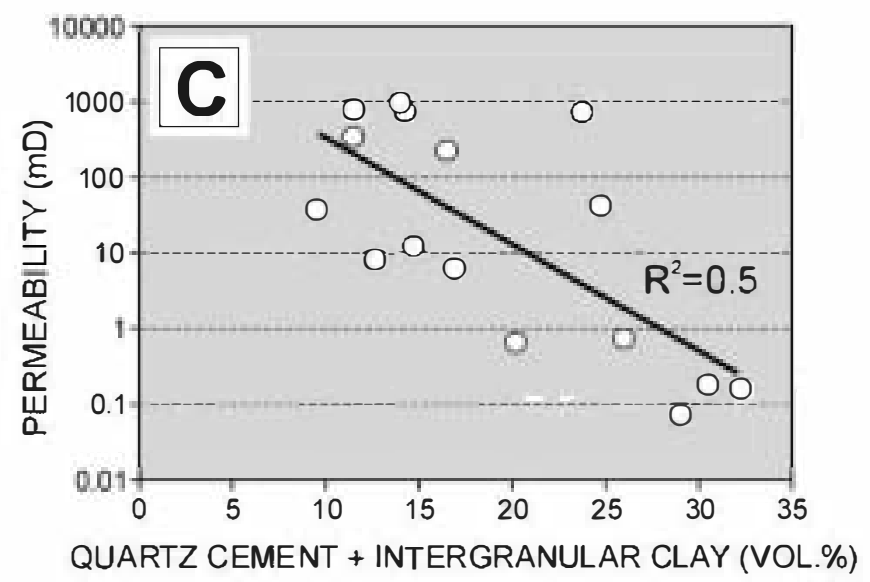

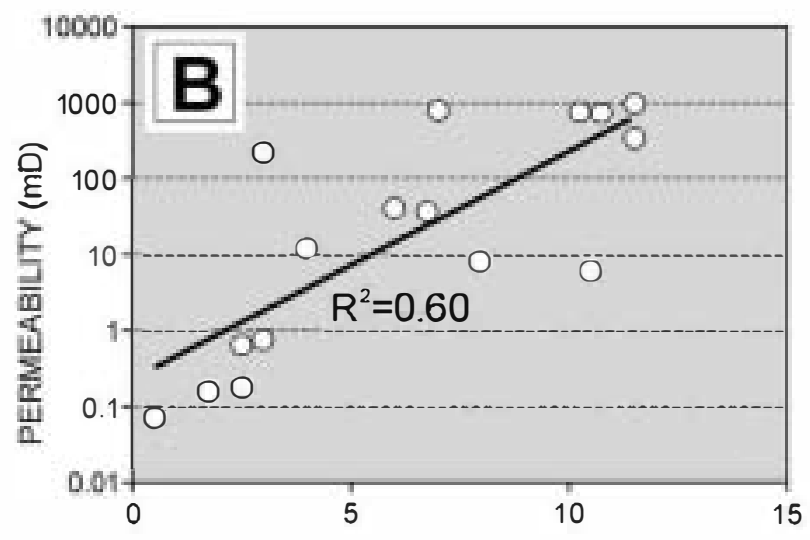

INTERGRANULAR MACROPOROSITY (\%)

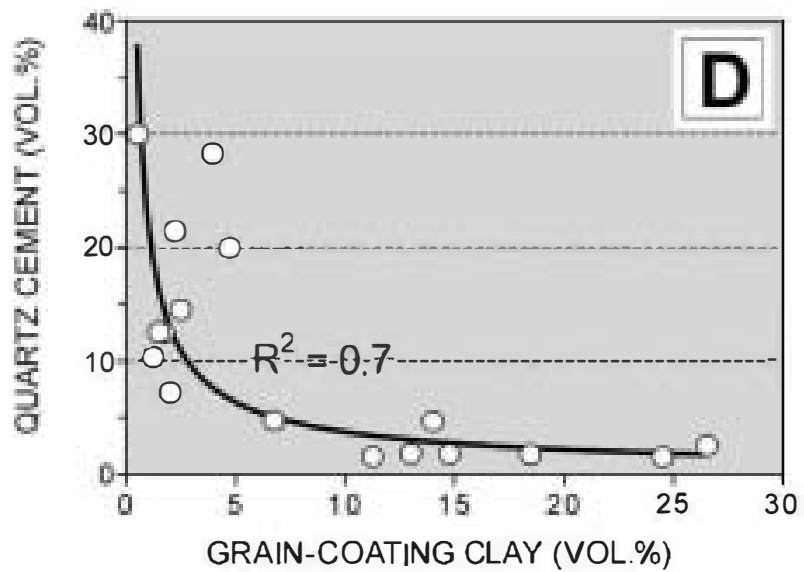

Fig. 12. Plots of porosity vs. quartz cement (A), permeability vs. intergranular macroporosity measure in thin section (B), permeability vs. quartz cement + intergranular clay (C) and quartz cement vs. grain-coating clay (D), for Lower TAGI sandstones.

\subsection{Reservoir properties}

Primary intergranular pores, bordered by quartz overgrowths (Fig. 11A) or clay coats (Fig. 11B), are the predominant pore type in all the sandstones examined. Secondary moldic and honeycomb pores, related to the dissolution of detrital and authigenic feldspar, are als• present (Fig. 11C). Secondary poresity is of very minor significance in the Lower TAGI, because of its very low initial feldspar contents. However, in the Middle-Upper TAGI secondary porosity contributes significantly $(2-4.75 \%)$ t॰ total pørısity.

\subsubsection{Lower TAGI}

Throughout the Løwer TAGI, reservoir quality is very variable and is mainly controlled by the content in graincoating clay and quartz cement. High contents in graincoating clay result in sandstones with packstone texture (e.g. subunit TL2), which have the lowest thin-section (TS) porosities $(<3 \%)$ and permeabilities $(<1 \mathrm{mD})$. Overall, He porosity is inversely correlated with quartz cement volume, especially if the samples with packstone texture and those extensively cemented by bitumen are excluded $\left(r^{2}=\mathbf{0 . 8 2}\right.$, Fig. 12A). Permeability is poorly correlated with grain size $\left(r^{2}=\mathbf{0} .34\right)$ and clay content $\left(r^{2}=\mathbf{0} .23\right)$, and moderately correlated with intergranular TS porøsity $\left(r^{2}=\mathbf{0 . 6}\right.$; Fig. 12B). Because this porosity is in turn mainly controlled by the combined effect of quartz cement and grain-coating clay, there is alsø a moderate correlation between permeability and the sum of quartz cement and grain-coating clay $\left(r^{2}=\mathbf{0 . 5}\right.$; Fig. 12C).

The abundance of quartz cement in the Løwer TAGI appears to be controlled primarily by grain-coating clay. There is a trend of decreasing quartz cement with increasing grain-cœating clay (Fig. 12D). Høwever, in clay-c at-pøor sandstones (i.e. $<5 \mathrm{v} \bullet 1 \%$ of grain-cœating clay), quartz cement varies widely $(7.5-30 \mathrm{v} \bullet 1 \%)$. S॰me $\bullet$ this variation may be related to the proximity of clay-rich facies, particularly towards the top of the Lower TAGI. Here, in clay-coat-pœor sandstones adjacent to mudstone beds, quartz cementation is extensive (28-30 v•l\%) (Fig. 13). Elsewhere in the Lower TAGI, quartz cementation in clay-coat-por sandstones is less extensive but variable $(7.5-21.5 \mathrm{v} \bullet 1 \%)$, and this variation is not clearly related to the proximity of clay-rich facies. In particular, this applies to the sandstones of subunit TL1, which have the best reservoir quality. They have relatively high $\mathrm{He}$ porosities (typically 14-16\%), in spite of the abundant 

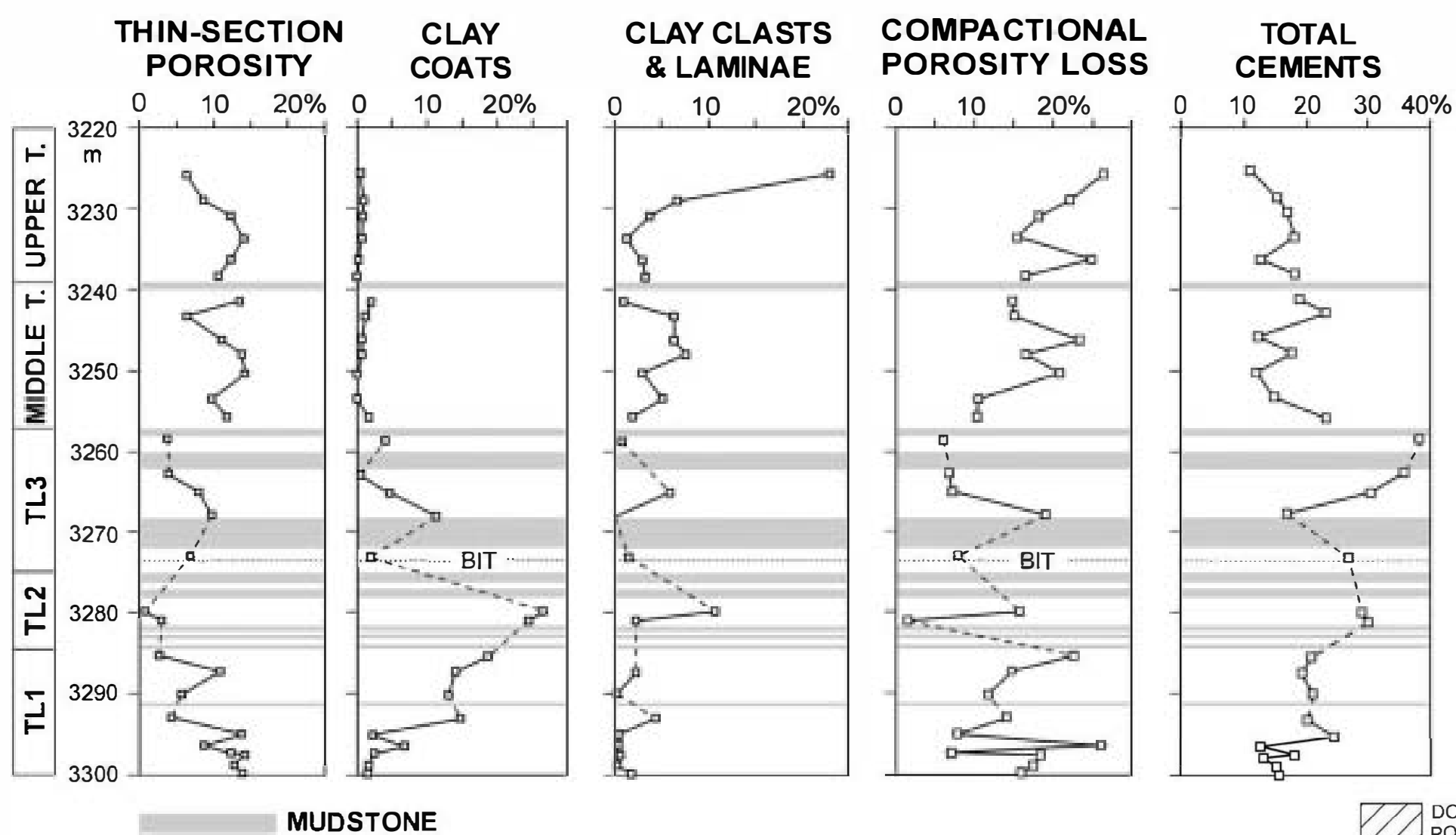
COMPACTION
INDEX

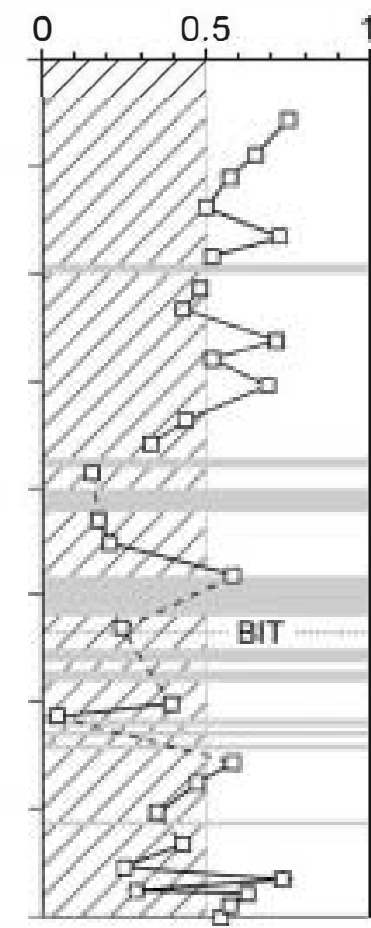

DOMINANCE OF CEMENTATIONAL
POROSITY LOSS

Fig. 13. Verical dis wibution of porosity and other selected parameters in the studie cored section, showing the location of mudstone intervals and the bitumen-cemente interval (BIT). 
quartz cement (typically between 12.5 and 21.5 v $1 \%$ ). Morever, their relative coarse grain size and the predominance of well-connected intergranular macropores, result in relatively high permeabilities. In subunit $T L 1$, the pøresity-permeability pattern is sømewhat different frøm the rest of the Løwer TAGI: in subunit TL1, the correlation between poresity and permeability is better $\left(r^{2}=\boldsymbol{0} .6\right)$, and permeabilities are higher and less variable than in the rest $\bullet$ the Løwer TAGI.

If the samples with packstone texture are excluded, the average He porosity is significantly lower in the Lower TAGI than in the Middle-Upper TAGI (13.7 vs. $16.6 \%$, respectively). Interestingly, the average content in quartz cement in these sandstones is $4 \%$ higher for the Lower TAGI than for the Middle-Upper TAGI, which suggests that quartz cementation is one of the main causes of the overall lower porosity of the Lower TAGI reservoir sandstones relative to those of the Middle-Upper TAGI.

\subsubsection{Middle-Upper TAGI}

In the studied cored section, reservoir quality is relatively homogeneous across this interval. Porosity slightly decreases up-section, probably as a result of increasing detrital-clay content. The lowest porosities relate t• elevated abundances of detrital clay (mud intraclasts and drapes) and thus tø higher degrees of compaction (see beløw). TS porosities usually vary between 9.5 and 14.2\% (Fig. 13). He porosities exceed TS porosities typically by $2-10 \%\left(r^{2}=\mathbf{0} .6\right)$, reflecting the presence of significant microporosity, which is contained within authigenic and detrital clays. Permeability is poorly correlated with He porosity $\left(r^{2}=0.4\right)$, and shows very poor correlations with grain size $\left(r^{2}=\mathbf{0} .16\right)$, clay content $\left(r^{2}=\right.$ ๑.19) and quartz cement $\left(r^{2}=\mathbf{0} .18\right)$. Similar t॰ porøsity, permeability als tends to decrease up-section and the lowest permeabilities are associated with the highest abundances in derital clay. The highest permeabilities correlate with coarser-grained lithølogies (medium-grained sandstones) and als with peaks in magnesite-siderite abundance.

In well B, log-deduced reserv $\bullet$ ir quality in the MiddleUpper TAGI section is significantly lower than in well A. Because this variation is not relate to differences in detrital composition, grain size or clay content, it might be related to differences in the degree or type of cementation. In fact, the total volume of the cements is significantly higher in well B (23-30\%) than in well A (11-22\%). This variation is mainly due to magnesite-siderite (mean values: 4 vol\% in well $\mathrm{A}$ vs. 12 vel\% in well $\mathrm{B}$ ) and sulfate (mean values: $1 \mathrm{v} \bullet 1 \%$ in well A vs. $4 \mathrm{v} \bullet 1 \%$ in well B) cements. However, these data must be treate with caution, as cutting samples tend to be biased towards more indurated lithølogies. Because dolømite cement is only present in well $\mathrm{B}$, it has contributed to the lower por osity in this well relative t• well A.
4.4.3. Compaction versus cementation in porosity reduction

In matrix-free sandstones, compactional porosity loss (COPL, sensu Lundegard, 1992; initial pørosities assessed after Beard and Weyl, 1973) ranges from 7 to 26\%, averaging $16 \%$, and is closely related the content in depositional clay (intraclasts, laminae, and grain coats) (Fig. 13). Moreover, dissølution features (sutured contacts and stylolites) are more abundant in clay-rich sandstones and in the clay-rich laminae of laminated sandstones, where porøsity is severely reduced by compaction (Fig. 6A). In the MiddleUpper TAGI, COPL ranges $10-26 \%$ and shows a poor correlation with detrital clay content $\left(r^{2}=\mathbf{0} .3\right)$ (Fig. 13). The lowest COPL values $(\sim 10 \%)$ are found towards the base, where they are related to the presence of precompactional magnesite cement (Fig. 9E), which presumably acted as a framework-strengthening cement that inhibited mechanical compaction. In the Lower TAGI, COPL is more variable and is controlled largely by the distribution -f grain-coating clay (Fig. 13).

The total volume of the cements is higher in the lower TAGI than in the Middle-Upper TAGI (Fig. 13). The higher cement volumes of the Løwer TAGI are related to greater abundances of quartz cement and grain-coating clay. The compaction index (ICOMP, sensu Lundegard, 1992) allows the assessment of the relative importance of compaction versus cementation in the reduction of the original poresity. By plotting of ICOMP versus depth (Fig. 13) it appears that in the Middle-Upper TAGI compaction is more important than cementation in reducing poresity, whereas in the Lower TAGI the contrary applies.

\section{Discussion}

\subsection{Provenance}

The Lower TAGI sandstones had their søurce in siliciclastic sedimentary rocks, as indicated by their high compsitional maturity, the predominance of monocrystalline quartz, which commonly bears inherited overgrowths, the scarcity $\bullet$ feldspar and mica, and the presence of sandstone rock fragments. In a QtFL diagram (Dickinsøn, 1985) (Fig. 4D), the Lower TAGI sandstones plot at the Qt pøle, which is consistent with a 'crat $\bullet$ interiør' prøvenance type (Dickinsøn, $\bullet$. cit.). S Surce røcks were likely Carbøniferøus and Devonian siliciclastics, which subcrop the Hercynian unconformity in the central Berkine Basin (Fig. 2). PreDevonian siliciclastics could have been additional sources, as they were alsø exposed during the Triassic aløng major paleohighs (Echikh, 1998). The presence of minor quantities of quartz grains showing bright red CL is consistent with a subordinate volcanic contribution (Owen, 1991). It is unclear however if this contribution reflects penecontempøraneous volcanism or if vølcanic quartz was recycled from Paleøzic strata.

By contrast, the Middle-Upper TAGI sandstønes derived 
mainly from metamorphic terrains, presumably from the Hoggar Massif to the south. Evidence for such kind of source terrain includes the presence of significant amounts -f feldspar, mica, and low-grade metamorphic rock fragments, and the relative high percentage of polycrystalline quartz. The overall predominance of brown-red luminescent quartz is als consistent with a metamorphic source (cf. Matter \& Ramseyer, 1985; Owen, 1991). Plotted in a QtFL diagram (Dickinsøn, 1985) (Fig. 4D), the detrital composition of the Middle-Upper TAGI sandstones indicates a provenance related the erosion of continental bløcks ('transitional continental' field in Dickinsøn's, ๑p. cit., diagram).

Near the base of the Middle TAGI, blue-luminescent quartz prevails, consistent with an influence of plutonic source rocks (cf. Owen, 1991). This inference is further supported by the local presence of granitic rock fragments. An additional influence of sedimentary source areas is evidenced by the presence of rare sandstone rock fragments. The influence of plutonic sources could have been related to the erosion of granitic basement in the Dahar paleohigh (cf. Mørad et al., 1994), which represents the northern limit of the Berkine Basin.

The marked difference in detrital composition between the Lower and Middle-Upper TAGI is thus caused by a change in provenance. This change may reflect an unroofing sequence related to progressive erosion of the flanks of the Heggar Massif. Alternatively, the change in compesition may have been caused by a variation in source area. In this case, the Lower TAGI could derive from local exp-sures of Paleøeic siliciclastics, whereas the Middle-Upper TAGI could mainly derive from more distant sources, such as the metamorphic terrains of the Hoggar massif.

\subsection{Origin of the authigenic phases}

\subsubsection{Vermicular kaolin}

In the studied sandstones, vermicular kaelin usually shows the blocky habit typical of dickite, whose presence is confirmed by XRD. Based on the presence of thin kaølin platelets interleaved with the bløcky kaolin crystals (Fig. 7), dickite is interpreted to have replaced, at least in part, previøusly formed kaølinite. The paragenetic timing of this ka linite is uncertain, but petrographic observations suggest a shallow burial origin (see abøve).

Because most kaølin occurs as sand-grade patches or within partly dissolved K-feldspar grains, the original precipitation of kalinite is interpreted to have been related to the dissolution of feldspar grains. Dissøution of feldspar and concomitant precipitation of kaolinite requires pore water with low $\left(\mathrm{K}^{+}, \mathrm{Na}^{+}\right) / \mathrm{H}^{+}$ratios and a mechanism to remove excess silica and $\left(\mathrm{K}^{+}, \mathrm{Na}^{+}\right)$from the system. Fluxing by freshwaters at shallow depths is a likely explanation for such kind of alteration of feldspars to kaølinite (Bjorlykke, 1998). Since the TAGI sandstones are fluvial in origin, they were fluxed by meteoric water immediately after depesition and als probably during the development of the subaerial unconformities that occur on top of the TAGI subunits.

Alternatively, acids from maturing hydrocarbon source rocks may have induced feldspar dissolution and, if $\mathrm{K}^{+}$ was exported (e.g. to adjacent mudrocks), the subsequent precipitation of kaolinite and quartz (e.g. Worden \& Barclay, 2000). However, if it is correct that kaolinite -riginally precipitated during shallow burial, this mechanism seems unlikely because organic matter maturation and clay-mineral reactions in mudrocks would require higher temperatures than these normally expected at shallow depths.

As discussed abøve, the original kaølinite was replaced by dickite. Such a replacement requires relatively high minimum temperatures $\left(80-130^{\circ} \mathrm{C}\right.$ ) and pore waters with low $\mathrm{K}^{+} / \mathrm{H}^{+}$ratios, since otherwise illite would form (Ehrenberg et al., 1993). A possible source of $\mathrm{H}^{+}$during burial diagenesis is the input of acids from maturing source rocks. Because $\mathrm{K}$-feldspars are abundant in the MiddleUpper TAGI, the input of acids would probably result in their dissolution and the subsequent release of $\mathrm{K}^{+}$. Therefore, in order to keep low $\mathrm{K}^{+} / \mathrm{H}^{+}$ratios, $\mathrm{K}^{+}$should have been removed from the system, for instance by exporting it to adjacent mudrocks (cf. Thyne, Boudreau, Ramm, \& Midtbø, 2001)

As deduced from SEM observations, dickitization is postdated by a late phase of illitization. The illitization of kaølin is favored by high $\mathrm{K}^{+} / \mathrm{H}^{+}$ratios and low water-torøck ratios (Mørad, Ketzer, \& De Røs, 2000). In sandstones, the $\mathrm{K}^{+}$required for late-diagenetic illitization is normally supplied by the dissolution of $\mathrm{K}$-feldspars (Bjorlykke, 1998). In the TAGI sandstones, petrography shows that there was a late-stage phase of dissolution of detrital and authigenic $\mathrm{K}$-feldspars that could have caused the partial illitization of kaølin. Illitization of kaølin in sandstones is favored at relatively high temperatures (normally above $100^{\circ} \mathrm{C}$ : Wilson \& Stanton, 1994) and by eil emplacement, which reduces the mobility of $\mathrm{K}^{+}$and thus prevents its possible export to adjacent mudstones (Thyne et al., 2001). Therefore, in the TAGI sandstones, the observed change from dickitization to illitization may reflect an increase in burial temperature and/or the onset of øil emplacement. In the Middle-Upper TAGI reservoir, present-day temperature and fluid content $\left(\sim 110^{\circ} \mathrm{C}\right.$, oil saturated) are consistent with a relatively recent timing for illitization.

\subsubsection{Fe-dolomite cement}

Fe-dølømite precipitated after minor compaction, as suggested by the kind of mutual contacts of søme of the detrital grains enclosed within dolømite cement (Fig. 8a,b), but at relatively shallow depths (n๑ more than a few hundred meters), as indicated by the high IGVs of the dolømitecemented areas. Because the TAGI is overlain by up to $\sim 150 \mathrm{~m}$ of Late Triassic and up t॰ $\sim 700 \mathrm{~m}$ of Liassic 


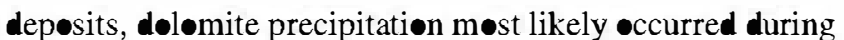
the latest Triassic or earliest Liassic.

The NE-trending field-bounding fault zone conditioned the distribution of dolømite cement. Dølømite is absent in well $\mathrm{A}$, and is very rare in other wells of the ORD field (Chris Carr, pers. comm.). However, in well B, which is the only well located in the downthrown block of the fault, dolømite is common throughout the Middle-Upper TAGI. This fault beløngs t• a regional system $\bullet$ extensional faults whose movement is mainly latest Triassic in age (Cochran \& Petersen, 2000). In the ORD field, this timing is supported by a significant thickness variation $(\sim 100 \mathrm{~m})$ - f the Late Triassic-earliest Liassic section across the fault zone. Because fault movement and dolømite cementation probably have similar timing, it is feasible that extensional faulting played a role in the distribution of dolømite cement, for instance by providing conduits for brine reflux.

The nature of the dolomite-precipitating waters cannot be establishe from the available data. However, taking int• account the burial history and ge $\bullet$ gical setting, it is likely that the dølømite precipitated from marine-derived waters. The TAGI is •verlain by a $\sim 850$-m-thick Late TriassicLiassic succession dominated by marginal marine evaporites. Large volumes of residual brine were undoubtedly generated during this prolonged period of evaporite deposition. Taking inte account that such brines have a high pøtential for deep penetration via density-driven reflux (e.g. Stanislavsky \& Gvirtzman, 1999), they most likely replace the original connate waters of the TAGI during its shallow burial history. The precipitation of dolømite from such brines is favored because they normally have high salinities and high $\mathrm{Mg} / \mathrm{Ca}$ ratios (Usdowski, 1994).

\subsubsection{K-feldspar cement}

K-feldspar •vergrowths pøstdate dolømite cement but, similar to dolomite, they predate significant compaction and thus formed at relatively shallow burial depths, probably below a few hundred meters of everburden. K-feldspar precipitation requires high silica activities and high $\mathrm{K}^{+} / \mathrm{H}^{+}$ ratios (Morad et al., 2000). Refluxed residual brines associated with the Liassic halite evaporites are possible søurces for $\mathrm{K}^{+}$. It is unlikely, however, that the aluminum and silica necessary for K-feldspar precipitation were supplied by these brines, given the low concentrations of silica and aluminum in sea waters. Therefore, it is more likely that aluminum and silica were internally sourced by the alteration of detrital silicates, particularly feldspars. As discussed abøve, during shallow burial the TAGI sandstones were probably fluxe by hypersaline brines, which are normally acidic (Han॰r, 1994) and thus capable of dissolving detrital feldspar. Other possible internal sources of silica, such as biøgenic silica, pressure sølution, $\bullet$ Illitization $\bullet$ smectitic clays, can be rule out because: biegenic silica is absent, $\mathrm{K}$-feldspar •vergrøwths predate pressure solution, and illitization of smectitic clays is temperature dependant and normally requires minimum burial depths of $1-2 \mathrm{~km}$
(Wood, 1994), inconsistent with the observation that $\mathrm{K}$ feldspar overgrowths predate significant compaction.

Due to the greater chemical stability of authigenic with respect to detrital feldspar, it is feasible for feldspar overgrowths to have precipitated concurrently with the dissolu-

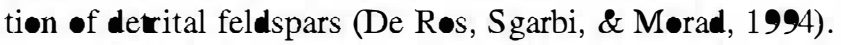
In the TAGI sandstones, the strong positive correlation between the contents in detrital and authigenic feldspar $\left(r^{2}=\mathbf{0 . 8 3}, N=30\right)$ is consistent with this possibility, but such correlation may be als influenced by the higher availability $\bullet$ suitable nucleation surfaces in the sandstones richer in detrital feldspar.

\subsubsection{Magnesite-siderite}

Petrography shows that magnesite-siderite cement is multiphase and precipitated over a range of burial depths. The earliest generation (MS1), composed by ferroan magnesite, precipitated during relatively shallow burial, as indicated by the high IGV preserved within MS1 patches. Later generations, mainly composed by magnesian siderite, postdate compaction and thus precipitated during deeper burial.

The precipitation of diagenetic magnesite requires pore fluids with $\mathrm{Mg} / \mathrm{Ca}$ molar ratios exceeding 40 (Aharon, 1988). Alsø, because aqueøus $\mathrm{Mg}^{2+}$ is highly hydrated and thus relatively unreactive, the formation of magnesite at relatively low temperatures requires solutions of very high iønic strength, which are given by chloride sølutions (Purvis, 1989; Usdowski, 1994). Magnesite precipitation is thus favered in halite-saturated evaporated sea waters, which are characterized by very high $\mathrm{Mg} / \mathrm{Ca}$ molar ratios and high ionic strength (Usdowski, 1994). In the Berkine basin, such brines were certainly generated during the depøsition of the Liassic evapørites, which include halite intervals exceeding $300 \mathrm{~m}$ in total thickness. Because the TAGI sandstones are located just below the evaporites, the residual brines should have migrated inte them by means of density-driven reflux. Therefore, the magnesite cements probably precipitated during shallow burial from residual brines, related the deposition of Liassic halite evaporites (cf. Garber, Harris, \& Borer, 1990; Purvis, 1989). The precipitation of the TAGI magnesites from connate meteoric waters is unlikely, because these waters normally have low $\mathrm{Mg} / \mathrm{Ca}$ ratios. Mørever, an enrichment in $\mathrm{Mg}$ of the initial meteoric waters is improbable because n- Mg-rich rocks (such as ultramafic rocks or non-marine evaporites) are known in the area.

The high $\mathrm{Fe}^{2+}$ content $\bullet$ the MS1 magnesites indicates availability of reduce $\mathrm{Fe}^{2+}$. Possible sources of $\mathrm{Fe}$ are the reduction of hematite and gøethite, common in the Lower TAGI, or chlorite and biøtite, present in minor amounts in the Middle-Upper TAGI. Later, burial-diagenetic more Ferich magnesite-siderite generations (MS2 and MS3) have compositions that indicate precipitation from waters with progressively higher $\mathrm{Fe} / \mathrm{Mg}$ ratios. 


\subsubsection{Quartz cement}

Quartz cement postdates significant compaction and has thus precipitated during relatively deep burial. It is likely that most of the silica required for quartz cementation was internally sourced by the pressure- or clay-induced dissolution of detrital quartz grains. This is suggested by the common presence of quartz dissolution features (intergranular dissolution contacts and stylølites) in most -f the sandstones examined. Alsø, in the Lower TAGI, this source of silica for quartz cement is suggested by the alternation $\bullet$ : (1) relatively clay-pøor sandstones rich in quartz cement, and (2) clay-coat-rich, more tightly compacted sandstones with little quartz cement and prominent quartz dissolution features.

As discussed above, in the Løwer TAGI sandstones quartz cement is inhibite by grain-coating clay. This inhibition effect is commonly reported in the literature and is normally atributed to the reduction in surface area available for nucleation of authigenic quartz (e.g. Ehrenberg etal., 1993; Fisher, Knipe, \& Worden, 2000). Grain-t•-grain dissolution features are better developed in clay-cœat-rich sandstones (Fig. 6A,C) than in nearby clay-cœat-pøor sandstones (Fig. 1 1A), indicating that intergranular illitic clays played a majør role in quartz dissølution (cf. Bjørkum, 1996). It is thus reasonable to assume that clay-coat-rich

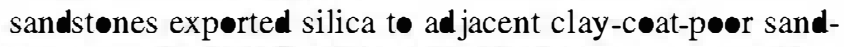
stønes. In the Middle-Upper TAGI, there is n॰ such alternation of clay-coat-pøor and clay-coat-rich sandstones, but grain-tø-grain dissølution features and stylølites are common.

Besides derital quartz disselution, clay-mineral reactions in intercalated mudstones might have contributed some additional silica for quartz cementation, especially in the Lower TAGI. This contribution would explain the anømaløusly high volumes of authigenic quartz $\bullet$ bserved in the clay-cœat-pøor sandstones from the uppermøst part -f the Lower TAGI, which occur intercalated between relatively thick mudstone intervals (Fig. 5).

Other possible additional source of silica for quartz cementation is the dissolution of $\mathrm{K}$-feldspar during burial diagenesis, which releases silica and may result in the precipitation of quartz and illite (e.g. Barclay \& Worden, 2000b; Bjørlykke \& Egeberg, 1993). If kaolin is present in the system, the dissolution of $\mathrm{K}$-feldspar may cause the illitization of kaølin, providing additional silica (Thyne et al., 2001). In the TAGI sandstones, petrography shows that a late-stage phase of dissolution indeed affects detrital and authigenic feldspar, and that some kaolin is illitized. Therefore, it is feasible that part of the silica required for quartz cementation is related with the late-stage dissolution of $\mathrm{K}$ feldspar. However, because of the very low original feldspar content $\bullet$ the Løwer TAGI sandstones, this pøtential søurce - silica could be significant only in the Middle-Upper TAGI. In any case, in this unit the average volume of feld-

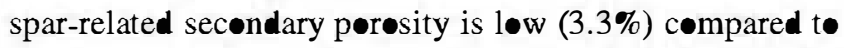
the average volume of authigenic quartz $(\mathbf{9 . 2 \%})$, and thus the contribution of feldspar-søurced silica tø quartz cement is probably subordinate.

At a local scale, the primary control on quartz cementation is the distribution of depositional clay, especially clay cøatings. For this reasøn, the vertical distribution of quartz cement abundance cann the used directly to evaluate the effect of $\bullet$ il charging $\bullet$ quartz cementation. It is kn॰wn that -il charge can slow down quartz cementation and thus explain preferential quartz cementation in water zones (Marchand, Haszeldine, Macaulay, Swennen, \& Fallick 2000; W orden \& B arclay, 2000; Worden, Oxt॰by, \& Smalley, 1998). In fact, the second quartz generation is thicker in the samples located below a prominent bitumen-cemented interval located close to the present-day OWC and likely formed by means of selective removal of water-søluble cœmpøunds from the petrøleum (cf. Barclay \& Wørden, 2000a).

\subsubsection{Sulfate cements}

Anhydrite and barite cements precipitated very late, because they postdate compaction and all the abovedescribed authigenic phases. Both sulfates are usually found together in the same patches, suggesting that they are genetically related. The scarcity of quartz $\bullet$ vergrowths inside some barite-anhydrite patches might indicate that søme sulfate predated quartz $\bullet$ vergrøwth (cf. Mørad et al., 1994). Nevertheless, anhydrite and barite usually replace previous phases, especially carbønates (Fig. 11G,H). As a consequence, the sulfates locally mimic the textural relationships of carbonate cements, which largely predate quartz cement. In conclusion, the scarcity $\bullet$ quartz $\bullet$ vergrowths inside certain sulfate patches is compatible with the precipitation of all sulfate after quartz cementation, since the sulfates may have replaced pre-quartz carbonate cements.

The sulfate necessary for anhydrite and barite formation was likely source by the dissolution of anhydrite, which is abundant in the evaporite sequence •verlying the TAGI. The deep subsurface dissolution of halite-anhydrite sequences normally produces sulfate-bearing brines (Hanor, 1994) from which anhydrite and barite cements may precipitate. Such a sulfate source has been demonstrated for numerous occurrences of late-stage barite and anhydrite cements in deeply buried sandstones from different basins (Dworkin \& Land, 1994; Gluyas, Jølley, \& Primmer, 1997; Greenwood \& Habesch, 1997; Sullivan, Haszeldine, Bøyce, Røgers, \& Fallick, 1994).

Other possible sources for the sulfate of the TAGI anhydrites and barites appear unlikely. Sea water is not a likely source because: (1) sulfate concentrations in marine waters are rapidly depleted with depth (Dworkin \& Land, 1994), and (2) the sulfates precipitated very late, when reflux $\bullet$ concentrated sea waters frøm the surface int the TAGI was improbable because of deep burial and sealing by a thick imperviøus evapørite section. The $\bullet x$ idation of pyrite is alsø an unlikely source of sulfate, because reducing conditions 


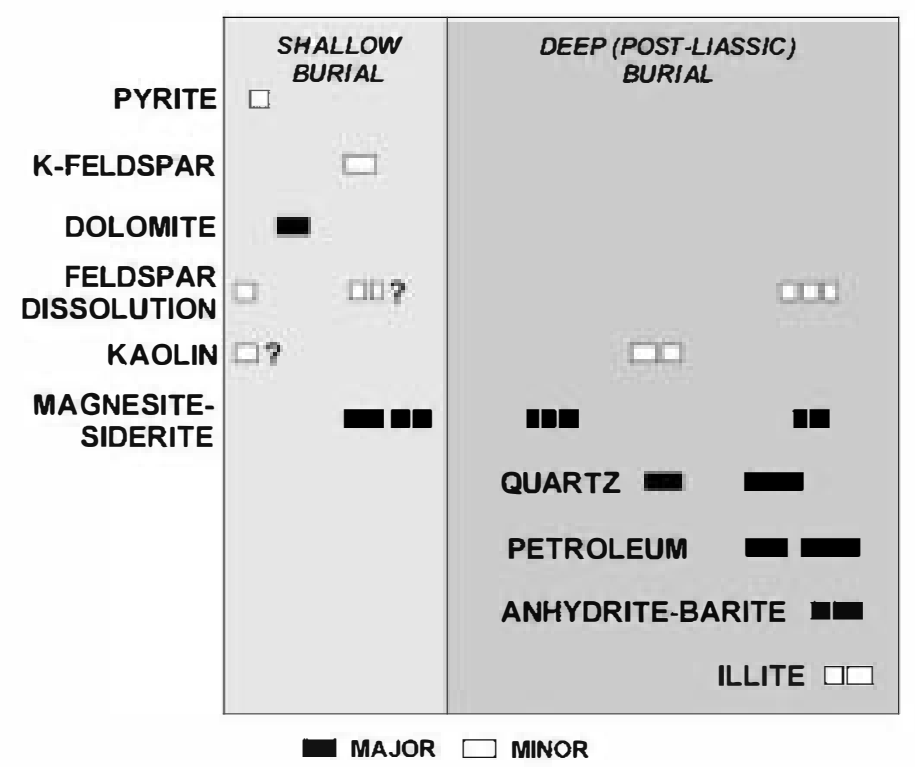

Fig. 14. Paragenetic sequence deduced from mutual textural relationships.

should normally prevail during the deep burial diagenesis $\bullet$ -il reservoir rocks.

The source of $\mathrm{Ba}^{2+}$ and $\mathrm{Ca}^{2+}$ for barite and anhydrite formation cannot be established from available data. However, an internal $\mathrm{Ba}^{2+}$ source is suggested by the stratigraphic distribution of barite cement, which is restricted to the Middle-Upper TAGI sandstones. A plausible internal $\mathrm{Ba}^{2+}$ source is the dissolution of detrital $\mathrm{K}$-feldspar, since (1) derital K-feldspars may contain barium, (2) petrgraphy has shown that $\mathrm{K}$-feldspar was partially disselved during late-stage diagenesis, when barite cements formed, and (3) the Middle-Upper TAGI sandstones contain abundant detrital K-feldspar, which is virtually absent in the Lower TAGI. Similarly t• barite, most anhydrite eccurrences are restricted to the Middle-Upper TAGI, which would be consistent with a contribution of internallysourced $\mathrm{Ca}^{2+}$.

Because anhydrite and barite are probably late diagenetic and show no signs of dissølution, the sulfate-precipitating waters could have been relatively similar to the present-day formation brines. In the Triassic sandstone reservoirs of the central Berkine Basin, these brines are extremely saline (>350 g/l), Cl-Na-Ca-Mg dominated, but contain significant sulfate (Askri et al., 1995; Ben Dhia \& Chiarelli, 1990; Mørad et al., 1994; J. Navarrø, pers. comm.). Althøugh the -rigin of these brines is probably complex, their extremely high salinity suggest that the diss lution of evaporites might have played a role in their formation (cf. Hanor, 1994). Some compositional features of the present-day brines, such as the presence of sulfate, contents in $\mathrm{Ca}$ higher than in $\mathrm{Mg}$, low $\mathrm{Br}$ concentrations, and low $\mathrm{Br} / \mathrm{Cl}$ ratios, are alsø consistent with a significant contribution of solutes derived frøm the dissolution - fhalite-anhydrite evaporites (Carpenter, 1978; Hanør, 1994). Aløng the SE border of the Berkine Basin, gravity-driven flow of meteoric waters is currently taking place through TAGI-equivalent sandstones (Ben Dhia \& Chiarelli, 1990; Bø॰te et al., 1998; Chiarelli, 1978; Echikh, 1998). Salinity gradients and potentiomeric data show that this flow does not currently affect the central part of the basin (Ben Dhia \& Chiarelli, 1990). However, we cannot exclude this possibility during past humid climatic phases, providing thus a possible mechanism for deep subsurface diss lution of the Liassic evaporites.

Based on mutual textural relationships and the above discussion, the interpreted relative chronøløy of the different diagenetic features is summarized in Fig. 14.

\subsection{Implications for reservoir quality}

Provenance has influenced reservoir quality mainly by conditioning the distribution of detrital feldspars, which caused significant variation in the diagenetic paths followed by the Lower TAGI quartz arenites and the Middle-Upper TAGI subarkoses.

Secondary porosity created by the dissolution of feldspar is only significant in the Middle-Upper TAGI, where it has contributed notably (mean: $3.3 \%$ ) to total porosity. However, this secondary porosity generation was balanced in part by the precipitation of by-products of feldspar dissolution, such as authigenic $\mathrm{K}$-feldspar (mean: 1.3\%) and ka lin (mean: 1.3\%). Furthermore, the precipitation of sulfate cements is largely restricted to Middle-Upper TAGI sandstones (mean: $\mathbf{0 . 7 \%}$ ), possibly because feldspar dissolution provided the required cations.

The precipitation of late-diagenetic illite may critically influence the permeability of feldspar-bearing sandstones (e.g. Ramm and Ryseth, 1996; Midtb et al., 2000). In the cored Middle-Upper TAGI section studied, however, illitization is incipient and thus seems not to be a critical factor for reservoir quality. This sandstone section is currently at 
3250 $\mathrm{m} \bullet$ f depth, where corrected present-day temperatures are $\sim 110^{\circ} \mathrm{C}$ (Yahi et al., 2001). Because illitization is influenced by temperature (Bjørlykke, 1998), the impact of late-diagenetic illite on permeability could be highly significant in more deeply buried Middle-Upper TAGI sandstone sections.

Other diagenetic factors, not directly controlled by detrital composition, have caused significant variation in reservoir quality within the TAGI. Compaction and especially quartz cementation are perhaps the most important. In the Lower TAGI, both factors are primarily controlled by the distribution of grain-coating clay, which is in turn facies controlled and thus potentially predictable. In the Lower TAGI, the content in grain-coating clay is statigraphically variable, resulting in major variations of reservoir quality. Besides, quartz cement seems to be the main cause for the -verall lower porøsity of the Lower TAGI sandstones with respect to the Middle-Upper TAGI sandstones.

Cementation by dolømite accounts for a significant lateral variation in porosity. The areal distribution and paragenetic timing of the dolømite is consistent with the interpretation that cementation was favered in the downthrown bleck of the NE-trending, field-bøunding fault. Porøsity reduction by magnesite-siderite cement is of subordinate importance and has not produced any significant vertical variation in reservoir quality, at least in the studied sections. By contrast, søme magnesite precipitated relatively early and thus may have acted as a framework-stengthening cement, inhibiting mechanical compaction, and thus contributing to porøsity preservation.

\section{Conclusions}

1. There is a significant change in detrital composition between the Lower and Middle-Upper TAGI sandstones, cause by a change in provenance. The Lower TAGI quartz arenites were probably derived from Paleøzic siliciclastic røcks. By contrast, the MiddleUpper TAGI subark oses most likely derive mainly from metamorphic terrains, presumably the Hoggar Massif, with a subordinate influence of granitic and sedimentary source areas. This change in provenance provides a pøtential criterion for stratigraphic correlation.

2. Grain-coating illitic and locally kaolinitic clays, common in the Lower TAGI sandstones, originated from pedogenesis and/or clay infiltration. Facies-related variations in the volume of grain-coating clay is one of the most important factors controlling the poresity and permeability of the Lower TAGI sandstones.

3. Shallow burial Fe-dolømite cementation occurred preferentially in the downthrown block of the NE-rending, field-bounding fault, causing significant lateral variations in porosity. Dolømite cementation was possibly related to the activity of this fault during the latest Triassic-earliest Liassic.
4. Magnesite-siderite cement is multiphase and precipitated over a range of burial depths. The earliest generation is composed by ferroan magnesite and precipitated during shalløw burial from pore fluids with $\mathrm{Mg} / \mathrm{Ca}$ molar ratios and very high ionic strength, possibly halite-saturated evaporated sea waters originated during the deposition of the Liassic evaporites and subsequently refluxed int the TAGI sandstones. Later magnesite-siderite generations precipitated during deeper burial from waters with progressively higher $\mathrm{Fe} / \mathrm{Mg}$ ratiøs. Porosity reduction by magnesite-siderite cements has not produced any significant vertical variation in reservoir quality, at least in the studied sections.

5. K-feldspar •vergrowths precipitated during shalløw burial. Silica and aluminum were probably derived internally from the dissolution of detrital feldspar. Refluxed hypersaline brines possibly provided protons and high potassium activities, necessary for detrital feldspar dissolution and $\mathrm{K}$-feldspar authigenesis, respectively.

6. The precipitation of authigenic vermicular kaølin was related to the dissolution of derital feldspar. Kaolin largely consists of dickite, which replaced previously formed kaøinite. Dickitization occurred during relatively deep burial, and was postdated by a late-stage phase of illitization linked to the dissolution of detrital and authigenic K-feldspar. The change from dickitization to illitization may reflect increasing burial temperature and/or •il emplacement. Illitization is incipient and does not critically affect reservoir quality, at least in the cored section studied.

7. Quartz cement precipitated during deep burial. A significant part of the silica was internally sourced by the dissolution of detrital quartz. Feldspar-related reactions (in the Middle-Upper TAGI) and clay-mineral reactions in intercalated mudstones (in the Lower TAGI) might have contributed additional silica for quartz cementation.

8. Quartz cement is one of the most important factors controlling the reservoir quality of the TAGI sandstones. Quartz cement is the main cause of the lower average porøsity of the Lower TAGI sandstones with respect to the Middle-Upper TAGI sandstones. The influence of quartz cement is particularly apparent within the Lower TAGI, where quartz cement abumdance is stratigraphically very variable and results in prominent vertical variations in porøsity and permeability. A large part of the variation in quartz cement is controlled by grain-coating clay, which in turn depends on depositional facies.

9. Anhydrite and barite cements precipitated very late. The sulfate necessary for their formation was likely sourced by the deep subsurface dissolution of the Late TriassicLiassic evaporites overlying the TAGI. Cations were possibly derived internally from the dissolution of feldspars in the Middle-Upper TAGI. 
10. Provenance has influence the diagenesis mainly by conditioning the distribution of detrital feldspars. Feldspar-related secondary poresity, authigenic K-feldspar, vermicular kaolin, and sulfate cements are largely restricted the Middle-Upper TAGI, but the influence on reservoir quality of these diagenetic products is probably higher for permeability than for pørøsity.

\section{Acknowledgements}

Cepsa and parmers in the ORD field (Sønarach, Anadark• Algeria Corp., Lasm•, Maersk, Burlingtøn Resøurces, and Talisman) kindly provided permission t• publish this work. Jorge Navarrø and Chris Carr (Cepsa) are particularly thanked for their encouragement and discussions, and Terence Eschner (Sarlan Resources) is thanked for his useful comments on an early version of the manuscript. Alfredo Fernández-Larios is thanked for his assistance with the electron microprobe. Richard Worden and an anonymous reviewer are thanked for their careful reviews and critical comments.

\section{References}

Acheche, M. H, M'Rabet, A., Ghariani, H, Ouahchi, A, \& Montgomery, S. L. (2001). Ghadames basin, southem Tunisia: a reappraisal of Triassic reservoirs and future prospectivity. American Association •f Petroleum Geologists Bulletin, 85, 765-78.

Alaron, P. (1988). A stable-isotope study of magnesites from the Rum Jungle uranium field, Auswalia; implications for the origin of stratabound massive magnesites. Chemical Geology, 69, 127-145.

Askri, H., Belmecheri, A., Benrabah, B., Boudjema, A., Boumendjel, K., Daoudi, M., Drid, M., Ghalem, T., Docca, A. M, Ghandriche, H., Ghomari, A., Guellati, N., Khemous, M., Lounici, R., Naili, H., Takherist, D., \& Terkmani, D. (1995). Geology of Algeria. In M. S. Beghoul, A. Ghomari \& M. Izem (Eds.), Well Evaluation Conference Algeria 1995 (pp. I1-193). Bath, UK: Schlumberger.

Barclay, S. A., \& Worden, R. H. (2004a). Effects of reservoir wettability on quartz cementation in oil fields. In R. H. Worden \& S. Morad (Eds.), Quartz cement in sand stone reservoirs. Special Publication of the International Association of Sedimentologists, 29, 103-117.

Barclay, S. A., \& Worden, R. H. (2000) beochemical modeling of diagenetic reactions in a sub-arkosic sandstone. Clay Minerals, 35, 57-67.

Beard, D. C., \& Weyl, P. K. (1973). Influence of texture on porosity and permeability of unconsolidated sand. In: Diagenesis -f Sandstones. American Association of Petroleum Geologists, Reprint series 20 , 349-369.

BenDia, H., \& Chiarelli, A. (1990). Hydrod ynamic framework of Saharan Triassic aquifers in South Tunisia and Algeria. Journal of African Earth Sciences, 10, 585-589.

Ben Tahar, H. (1991). Stratigraphy and sedimentology of Triassic sandstones, El Borma oil freld and southern Tunisia. $\mathrm{Pb} \mathbf{D}$ dissertation, Colorado State University, $184 \mathrm{pp}$.

Bjørkum, P. A. (1996). How important is pressure in causing dissolution of quartz in sandstones? Joumal of Sedimentary Research, 66, 147-154.

Bjørlykke, K. (1998). Clay mineral diagenesis in sedimentary basins: a key to the prediction of rock properties. Examples from the North Sea Basin. Clay Minerals, 33, 15-34.

Bjørlykke, K., \& Egeberg, P. K. (1993). Quartz cementation in sedimentary basins. American Association of Petroleum Geologists Bulletin, 77, $1538-1548$.

Bloch, S. (1994). Effect of Derital Mineral Composition on Reservoir
Quality. In M. D. Wilson (Ed.), Reservoir Quality Assessment and Prediction in Clastic Rocks. Society of Economic Paleontologists and Mineralogists Short Course, 30, 161-182.

Boote, R. D., Clark-Lowes, D. D., \& Traut, M. W. (1998). Paleozoic peroleum systems of North Africa. In $\mathbf{D}$. S. MacGregor, R. T. J. Moody \& $\mathbf{D}$ D. Clark-Lowes (Eds.), Petroleum geology of North Africa. Geological Society of London Special Publication, 132, 7-68.

Boudjema, A. (1987). Evolution structural du bassin petrolier-Triassique-du Sahara Nord Oriental (Algérie). These l'Université de ParisSud, Centre d'Orsay, Paris, Editions Technip, 279 pp.

Carney, S. R., Peffer, J. W., Pink, A., Drumheller, R. E., Jasek, J. H., Hadjali, M., \& Bouazza, L. (1999). The Hassi Berkine South (HBNS) Field, Block 44, Berkine Basin, Algeria. American Association of Petroleum Geologists, Annual Meeting, Expanded Abswacts, San Antonio, Texas, United States, p. A21.

Carpenter, A. B. (1978). Origin and chemical evolution of brines in sedimentary basins. Oklahom Geological Survey Circular, 79, 78-88.

Chiarelli, A. (1978). Hydrodynamic framework of eastern Algerian Sahara-influence on hydrocarbon occurrence. American Association -f Petroleum Geologists Bulletin, 62, 667-685.

Cochran, M. D., \& Petersen, L. E. (2000). Hydrocarbon exploration in the Berkine Basin, Grand Erg Oriental, Algeria. Second Wallace E. Pratt Memorial Conference on Peroleum Provinces of the 21st Century, San Diego, Califomia, January 12-15, 2000. American Association of Petroleum Geologists, $28 \mathrm{pp}$.

Daniels, R. P, Hook, R. C., Sorensen, P. R., \& Emme, J. J. (1994). Triassic depositional system and reservoir development, Ghadames Basin, Algeria. American Association of Petroleum Geologists. Annual Convention, Annual Meeting Abstracts, p. 131.

De Ros, L. F., Sgarbi, G. N. C., \& Morad, S. (1994). Multiple authigenesis of K-feldspar in sandstones; evidence from the Cretaceous Areado Formation, Sao Francisco Basin, central Brazil. Journal of Sedimentary Research, 64, 778-787.

Dickinson, W. R. (1985). Interpreting provenance relations from derital modes of sandstones. In G. G. Zuffa (Ed.), Provenance of arenites. NAT ASI Series, vel. 148 (pp. 333-361). Dordrecht: Reidel.

Dworkin, S. I., \& Land, L. S. (1994). Petrographic and geochemical conswaints on the fornation and diagenesis of anhydrite cements, Smackover sandstones, Gulf of Mexico. Journal of Sedimentary Research, A64, 339-348.

Echikh, K. (1998). Geology and hydrocarbon occurrences in the Ghadames Basin, Algeria, Tunisia, Libya. In D. S. MacGregor, R. T. J. Moody \& D. D. Clark-Lowes (Eds.), Petroleum geology of North Africa. Geological Society of London Special Publication, 132, 109-130.

Ehrenberg, S. N., Aagaard, P., Willson, M. J., Fraser, A. R., \& Duthie, D. M. L. (1993). Depth-dependent ansfornation of kaolinite to dickite in sandstones of the Nonwegian continental shelf. Clay Minerals, 28, 325-352.

Fisher, Q. J., Knipe, R. J., \& Worden, R. H. (2000). Microstuctures of deforme and non-deformed sandstones from the North Sea: Implicaions for the origins of quartz cement in sandstones. In R. H. Worden \& S. Morad (Eds.), Quartz cement in sandstone reservoirs. Special Publication of International Association of Sedimentologists, 29, 129-146.

Ford, G. W., \& Scott, A. J. (1997). A depositional model and sequence stratigraphy of the Trias Argilo-Greseux Inferieur (T.A.G.I.) in the Ghadames Basin, Algeria. American Association of Petroleum Geologists, 1997 Annual Convention Abstracts, p. 36.

Garber, R. A., Harris, P. M., \& Borer, J. M. (1990). Occurrence and significance of magnesite in Upper Permian (Guadalupian) Tansill and Yates Formations, Delaware Basin, New Mexico. American Association of Petroleum Geologists Bulletin, 74, 119-134.

Gautbier, F. J., Boudjema, A., \& Lounis, R. (1995). The swuctural evolution off the Ghadames and lizi basins during the Paleozoic, Mesozoic, and Cenozoic; petroleum implications. AAPG International Conference and Exbibition, Abswacts. American Association of Petroleum Geologists Bulletin, 79, 1214-1215.

Gluyas, J., \& Cade, C. A. (1997). Prediction of porosity in compacted sands. In J. A. Kupecz, J. Gluyas \& S. Bloch (Eds.), Reservoir quality 
prediction in sandstones and carbonates. American Association of Petroleum Geologists Memoir, 69, 19-28.

Gluyas, J., Jolley, L., \& Primmer, T. J. (1997). Element mobility during diagenesis; sulfate cementation of Rotliegend sandstones, southern North Sea. Marine Petroleum Geology, 14, 1001-1011.

Greenwood, P. J., \& Habesch, S. M. (1997). Diagenesis of the Sherwood Sandstone Group in the southern East Irish Sea basin (blocks 110/13, 110/14 and 110/15); conswaints from preliminary isotopic and fluid inclusion studies. In N. S. Meadows, S. P. Trueblood, M. Hardman \& G. Cowan (Eds.), Petroleum geology of the Irish Sea and adjacent areas. Geological Society of London Special Publication, 124, 353371.

Hanor, J. S. (1994). Origin of saline fluids in sedimentary basins. In J. Pamell (Ed.), Geofluids: Origin, migration and evolution of fluids in sedimentary basins. Geological Society of London Special Publication, 78, 151-174.

Jackson, J. S., Moore, S. R., Quarles, A. I., \& Bellis, J. (1996). PostPaleozoic defonnation in the Triassic Basin, North Africa. American Association of Petroleum Geoløgists, Annual Convention, San Diego, United States, Abstracts, p. 70.

L undegard, P. D. (1992). Sandstone porosity loss - a 'big picture' view of the importance of compaction. Journal of Sedimentary Petrology, 62, $250-260$

MacGregor, D. S. (1998a). Introduction. In D. S. MacGregor, R. T. J. Moody \& D. D. Clark-Lowes (Eds.), Petroleum geoløgy of North Africa. Geological Society of London Special Publication, 132, 1-6.

MacGregor, D. S. (1998b). Giant fields, petroleum systems and exploration maturity of Algeria. In D. S. MacGregor, R. T. J. Moody \& D. D. ClarkLowes (Eds.), Petroleum geology of North Africa. Geological Society - London Special Publication, 132, 79-96.

Makhous, M., Galushlin, Y., \& Lopatin, N. (1997). Burial history and kineric modeling for hydrocarbon generation, Part II: Applying the GALO model to Saharan basins. American Association of Petroleum Geologists Bulletin, 81, 1679-1699.

Marchand, A. M. E., Haszeldine, R. S., Macaulay, C. I., Swemen, R., \& Fallick, A. E. (200). Quartz cementation inhibited by crestal oil charge; Miller deep water sandstone, UK North Sea. Clay Minerals, $35,21-210$

Matter, A., \& Ramseyer, K. (1985). Cathodoluminescence microscopy as a tool for provenance study of sandstones. In G. G. Zuffa (Ed.), Provenance of arenites. NAT ASI series, vel. 148 (pp. 191-211). Dordrecht: Reidel.

Midtb $\varnothing$, R. E. A., Rykkje, J. M., \& Ramm, M. (200)). Deep burial diagnesis and reservoir quality along the eastern flank of Viking Graben; evidence for illitization and quartz cementation after hydrocarbon emplacement Clay Minerals, 35, 227-237.

Morad, S., Ben Ismail, H., De Ros, L. F., Al-Aasm, I. S., \& Serribini, N. E. (1994). Diagenesis and fonnation waters chemiswy of Triassic reservoir sandstones from southern-Tunisia. Sedimentoløgy, 41, 1253-1272.

Morad, S., Ketzer, J. M., \& De Ros, F. (200). Spatial and temporal diswibution of diagenetic alterations in siliciclastic rocks: Implications for mass wansfer in sedimentary basins. Sediment॰l॰gy, 47, 95-120.

Moraes, M. A. S., \& DeRos, L. F. (1990). Infilmated clays in fluvial Jurassic sandstones of Reconcavo Basin, northeastern Brazil. Journal of Sedimentary Petrology, 60, 819-819.

Morton, A., \& Hurst, A. (1995). Correlation of sandstones using heavy minerals: An example from the Statfjord Formation in the Snorre Field, northern North Sea. In R. E. Dumay \& E. A. Hailwood (Eds.), Non-biostratigraphical methods of dating and correlation. Geological Society of London Special Publication, 89, 3-22.

Owen, M. R. (1991). Application of cathodoluminescence to sandstone provenance. In C. E. Barker \& O. C. Kopp (Eds.), Luminescence micrscopy: Quantitative and qualitative aspects. Society of Econ॰mic Paleontologists and Mineralogists Short Course, 25, 67-75.

Pittman, E. D. (1992). Artifact porosity in thin sections of sandstones. Journal of Sedimentary Petroløgy, 62, 734-737.
Pittman, E. D., Larese, R. E., \& Mea1d, M. T. (1992). Clay coats: Occurrence and relevance to preservation of porosity. In $\mathbf{D}$. W. Houseknecht \& E. D. Pittman (Eds.), Origin, diagenesis, and petrophysics of clay minerals in sandstones. Society of Economic Paleontologists and Mineralogists Special Publication, 47, 241-255.

Purvis, K. (1989). Zoned autbigenic magnesites in the Rotliegend Lower Pennian, southern North Sea. Sedimentary Geology, 65, 307-318.

Ramm, M., \& Ryseth, A. E. (1996). Reservoir quality and burial diagenesis in the Statfjord Formation, North Sea. Petroleum Geoscience 2, 313324.

Scott, A. J., \& Howells, C. (200). Analogues for the Trias Argil-Gréseux Inferieur (TAGI), Berkine Basin, Algeria. Tuming the Conventional int the Unconventional, an Integrated Approach. Sonatrach JST-4 Conference, April 2006, Algiers, Algeria.

Scott, A. J., \& Wheller, D. A. (1999). Regional wends in Triassic fluviallacustrine cycles, Berkine Basin, Algeria. American Association of Petroleum Geologists Annual Meeting Expanded Abstracts, San Antonio, Texas, Unite States, p. A126.

Shirley, K. (2000). Big implications for supply needs-discoveries are getting smaller. American Association of Petroleum Geologists Explorer, January, 6-14.

Stanislavsky, E., \& Gvirtzman, H. (1999). Basin-scale migration of continental-rift brines: Paleohydrologic modeling of the Dead Sea basin. Geology, 27, 791-794.

Sullivan, M. D., Haszeldine, R. S., Boyce, A. J., Rogers, G., \& Fallick, A. E. (1994). Late anhydrite cements mark basin inversion; isotopic and formation water evidence, Rotliegend Sandstone, North Sea. Marine Petroleum Geology, 11, 46-54.

Thyne, G., Boudreau, B. P., Ramm, M., \& Midtbø, R. E. (2001). Simulation of potassium feldspar dissolution and illizization in the Statfjord Fonnation, North Sea. American Association of Petroleum Geoløgists Bulletin, 85, 621-637.

Turner, P., Pilling, D., Walker, D., Exton, J., Binnie, J., \& Sabaou, N. (201). Sequence stratigraphy and sedimentology of the late Triassic TAGI-I (Blocks 41-402, Berkine Basins, Algeria). Marine Petroleum Geology, 18, 959-981.

Usdowski, E. (1994). Synthesis of dolomite and geochemical implications. In B. Purser, M. Tucker \& D. Zenger (Eds.), Dolomites. Special Publication of the International Association of Sedimentologists, 21 , 345-36.

Walker, T. R., Waugh, B., \& Crone, A. J. (1978). Diagenesis in first cycle desert alluvium of Cenozoic age, southwestern United States and northwestem Mexico. Geological Society of America Bulletin, 89, 19-32.

Wheller, D. A., Carney, S. R., Drumheller, R. E., Winstanley, S. I., Hadjali, M., \& Scott, A. J. (1999). Sedimentology and reservoir characterization of the Hassi Berkine South (HBNS) Field, Block 44, Berkine Basin, Algeria. American Association of Petroleum Geologists International Conference and Exbibition, Birmingham, United Kingdom. American Association of Petroleum Geologists Bulletin, 83, p. 1345.

Wilson, M. D., \& Stanton, P. T. (1994). Diageneric mechanisms of porosity and permeability reduction and enhancement. In M. D. Wilson (Ed.), Reservoir quality assessment and prediction in clastic rocks. Society -f Economic Paleontologists and Mineralogists Short Course, $3 \mathbf{0 ,}$ 59-118.

Wood, J. R. (1994). Chemical diagenesis. In M. D. Wilson (Ed.), Reservoir

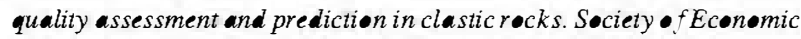
Paleontologists and Mineralogists Short Course, 30, 119-136.

Worden, R. H., \& Barclay, S. A. (2000). Internally-sourced quartz cement due to externally-derive $\mathrm{CO}_{2}$ in sub-arkosic sandstones, North Sea. Joumal of Geochemical Exploration, 69-70, 645-649.

Worden, R. H., Oxtoby, N. H., \& Smalley, P. C. (1998). Can oil emplacement prevent quartz cementation in sandstones? Petroleum Geoscience, 4, 129-137.

Yahi, N., Schaefer, R. G., \& Littke, R. (201). Petroleum generation and accumulation in the Berline basin, eastern Algeria. American Association of Petroleum Geoløgists Bulletin, 85, 1439-1467. 